OECD Environment Working Papers No. 95

\title{
Exploring the Effect of Urban Structure on Individual Well-Being
}

\section{Zachary S. Brown, \\ Walid Oueslati, \\ Jérôme Silva}


Organisation de Coopération et de Développement Économiques

Organisation for Economic Co-operation and Development

20-Nov-2015

ENVIRONMENT DIRECTORATE

English - Or. English

\section{EXPLORING THE EFFECT OF URBAN STRUCTURE ON INDIVIDUAL WELL-BEING -} ENVIRONMENT WORKING PAPER No. 95

By Zachary S. Brown (1), Walid Oueslati (2) and Jérôme Silva (2)

(1) NC State University, Dept. of Agricultural \& Resource Economics

(2) OECD, Environment Directorate

OECD Working Papers should not be reported as representing the official views of the OECD or of its member countries. The opinions expressed and arguments employed are those of the author(s).

Authorised for publication by Simon Upton, Director, Environment Directorate.

JEL Codes: life satisfaction, urban structure, land-use, compactness, monocentric city model

Keywords: Q51, Q56, R13, R14, I31

OECD Environment Working Papers are available at www.oecd.org/environment/workingpapers.htm

JT03386605

Complete document available on OLIS in its original format

This document and any map included herein are without prejudice to the status of or sovereignty over any territory, to the delimitation of international frontiers and boundaries and to the name of any territory, city or area. 


\section{OECD ENVIRONMENT WORKING PAPERS}

OECD Working Papers should not be reported as representing the official views of the OECD or of its member countries. The opinions expressed and arguments employed are those of the author(s).

OECD Working Papers describe preliminary results or research in progress by the author(s) and are published to stimulate discussion on a broad range of issues on which the OECD works.

This series is designed to make available to a wider readership selected studies on environmental issues prepared for use within the OECD. Authorship is usually collective, but principal author(s) are named. The papers are generally available only in their original language -English or French- with a summary in the other language.

Comments on OECD Working Papers are welcomed, and may be sent to:

OECD Environment Directorate, 2, rue André Pascal, 75775 PARIS CEDEX 16, France or by e-mail to env.contact@oecd.org.

OECD Environment Working Papers are published on www.oecd.org/environment/workingpapers.htm

This document and any map included herein are without prejudice to the status of or sovereignty over any territory, to the delimitation of international frontiers and boundaries and to the name of any territory, city or area.

The statistical data for Israel are supplied by and under the responsibility of the relevant Israeli authorities. The use of such data by the OECD is without prejudice to the status of the Golan Heights, East Jerusalem and Israeli settlements in the West Bank under the terms of international law.

\section{(C) OECD (2015)}

You can copy, download or print OECD content for your own use, and you can include excerpts from OECD publications, databases and multimedia products in your own documents, presentations, blogs, websites and teaching materials, provided that suitable acknowledgment of OECD as source and copyright owner is given. All requests for commercial use and translation rights should be submitted to rights@oecd.org 


\begin{abstract}
Building on the OECD's Better Life Initiative and new work using geospatial analysis, this paper investigates how reported life satisfaction relates to some of the urban structure indicators. To this end, it merges OECD household survey data with urban structure data from OECD's Metropolitan Database, which includes a number of city-level indicators such as population and road density, as well as localised measures of land-use. The merged data permit analysis for five countries: France, Japan, the Netherlands, Spain and Sweden.

The findings from this analysis provide some evidence of a trade-off between home size and distance to the city centre, although the statistical power of this effect is relatively weak. Interestingly, regression analysis suggests that overall city-level compactness has a clear negative relationship with life satisfaction, regardless of whether individuals live in the urban core or in peri-urban areas. Land-use fragmentation is also found to have a negative relationship with individuals' life satisfaction. These general patterns are for the most part robust to various statistical tests. They also hold when econometric analysis is conducted at the country level. Residents of cities with greater levels of centralisation - i.e. a greater share of the population living in the city centre - exhibit measurably lower levels of life satisfaction. A naïve interpretation of this result would suggest that anti-sprawl policies do not in fact improve overall welfare. This study does not support this conclusion. It does, however, give cause for consideration before accepting 'win-win' arguments for 'smart growth,' often brought forward to support increasingly concentrated, high-density development. The evidence presented here suggests that such policies are not without their welfare trade-offs, and that there will be winners and losers from their implementation. While high-density policies can clearly make a positive contribution to reducing local and global environmental externalities, many of these benefits are deferred and may largely accrue to future generations.

A key general lesson from this study is that compensation of the losers may improve the equity effects of these policies, as well as prove more expeditious from a political economy perspective. One of the simplest approaches to compensation would be to balance pecuniary incentives for smart growth, such as higher development taxes or fees, with compensatory policies, such as subsidies or tax or fee offsets in other domains. The main policy conclusion from this study is that smart growth policies should include distributional analysis and recommendations for addressing concerns about inequalities flowing from the scoping and implementation of policies.
\end{abstract}

JEL Classification: Q51, Q56, R13, R14, I31

Keywords: life satisfaction, urban structure, land-use, compactness, monocentric city model 


\section{RÉSUMÉ}

En s'appuyant sur l'initiative du Vivre mieux de l'OCDE et sur les nouveaux travaux fondés sur des analyses géospatiales, ce rapport étudie les relations entre le niveau de satisfaction déclaré par les ménages et certains des indicateurs de structure urbaine. Pour ce faire, il croise les données d'enquête ménages de l'OCDE et les données sur la structure urbaine tirées de la base de données métropolitaines de l'OCDE, qui réunit plusieurs indicateurs urbains tels que les densités démographique et routière, et des mesures localisées de l'occupation des sols. Ce travail a permis de produire des analyses pour cinq pays : l'Espagne, la France, le Japon, les Pays-Bas et la Suède.

Les résultats de ces analyses confirment qu'il existe une relation inverse entre la taille des logements et l'éloignement du centre-ville, même si la significativité statistique de cet effet est relativement faible. Notons aussi que l'analyse empirique révèle l'existence d'une corrélation négative incontestable entre la compacité urbaine et la satisfaction à l'égard de la vie, que l'on habite au cœur des villes ou en périphérie. Même constat en ce qui concerne la fragmentation urbaine. Ces schémas généraux sont pour la plupart validés par différents tests statistiques et confirmés à l'échelle de chaque pays. Les habitants des villes dont le niveau de centralisation est plus élevé - en d'autres termes, les villes où la part de la population vivant dans le centre est supérieure - affichent un niveau de satisfaction à l'égard de la vie bien plus faible. Une interprétation naïve de ce résultat consisterait à dire que les mesures visant à lutter contre l'étalement urbain n'améliorent pas le bien-être global. Le présent rapport ne soutient pas cette conclusion. En effet, ce constat empirique révèle plutôt qu'il est nécessaire d'arrêter de retenir les arguments " gagnant-gagnant » en faveur de la «croissance intelligente », souvent mis en avant pour soutenir un développement urbain favorable à une concentration et une densité de plus en plus fortes. Les constatations présentées dans le présent document font apparaître que ces politiques ne présentent pas que des avantages en termes de bienêtre, et que leur mise en œuvre profitera à certains individus au détriment des autres. Si les politiques en faveur d'une haute densité urbaine peuvent avoir un impact positif en réduisant les externalités environnementales à l'échelle locale et mondiale, nombre de leurs avantages sont différés dans le temps et ne profiteront sans doute en grande partie qu'aux générations futures.

L'un des enseignements essentiels à tirer de cette étude tient au fait que l'on pourrait améliorer l'équité des politiques urbaines en offrant une compensation aux individus lésés par ces mesures. L'une des méthodes les plus simples consisterait à équilibrer les incitations pécuniaires en faveur d'une croissance intelligente en introduisant des dispositifs compensatoires tels que des subventions, des taxes ou des redevances dans d'autres domaines. Ce n'est qu'un exemple parmi tout un éventail de mesures possibles. Enfin, la conclusion principale à tirer sur le plan de l'action publique consiste à dire que les mesures en faveur d'une croissance intelligente devraient comporter une analyse des effets redistributifs ainsi que des recommandations pour faire face aux problèmes d'inégalités lors de leur cadrage et de leur mise en œuvre.

Classification JEL : Q51, Q56, R13, R14, I31

Mots-clés : satisfaction dans la vie, structure urbaine, occupation des terres, compacité urbaine, modèle de ville monocentrique 


\section{FOREWORD}

The paper has been authored by Zachary S. Brown (North Carolina State University, Department of Agricultural \& Resource Economics), Walid Oueslati and Jérôme Silva (OECD Environment Directorate). The authors are grateful to delegates to the Working Party on Integrating Environmental and Economic Policies for helpful comments on earlier drafts of this paper. They would also like to thank Alexandros Dimitropoulos, Rudiger Ahrend and Monica Brezzi, for comments on previous versions of the paper and Natasha Cline-Thomas for editorial assistance. The authors are responsible for any remaining omissions or errors. Work on this paper was conducted under the overall responsibility of Shardul Agrawala, Head of the Environment and Economy Integration Division. 


\section{TABLE OF CONTENTS}

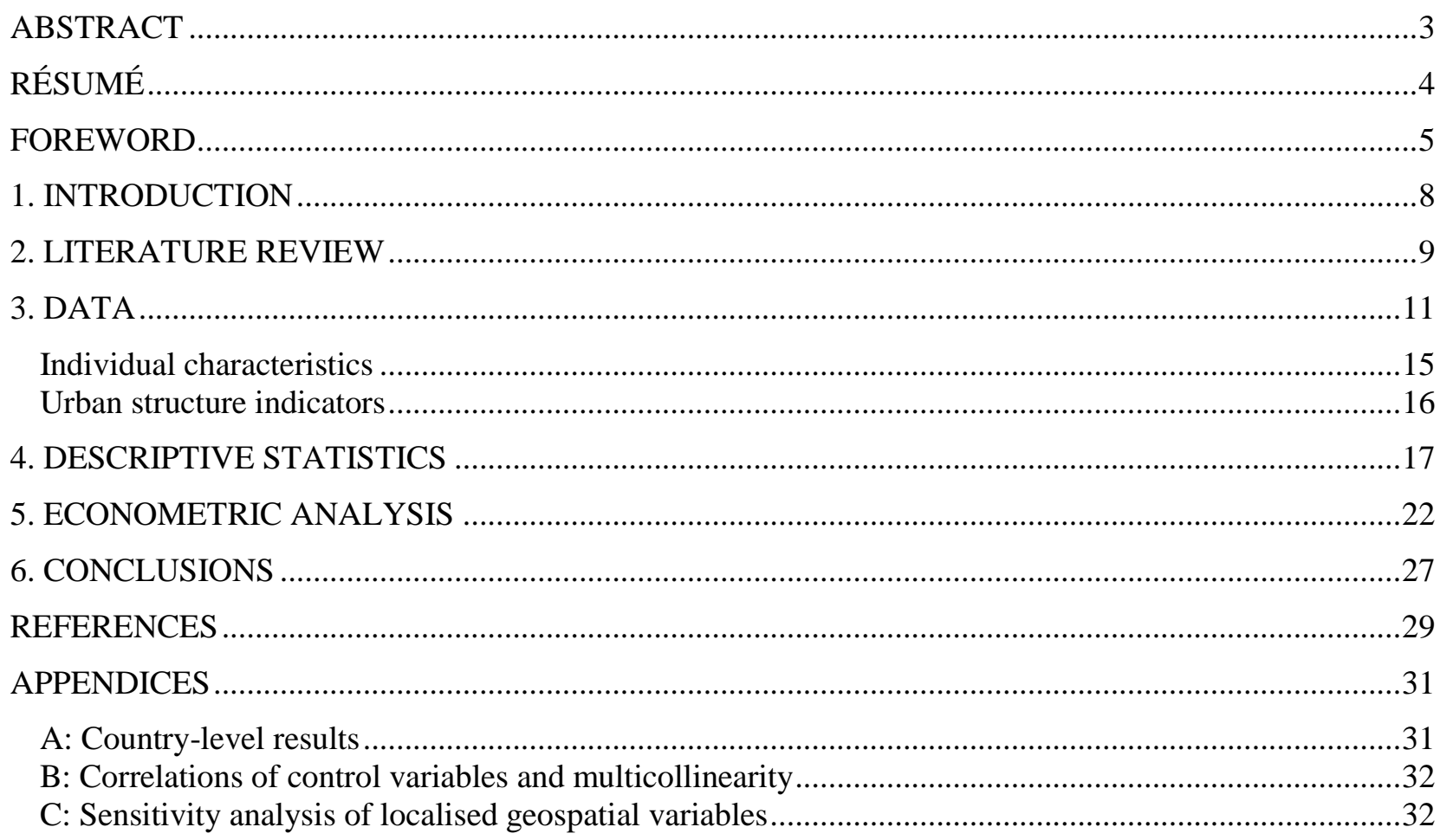

\section{Tables}

Table 1: Sample sizes in selected countries and in metropolitan areas (MA) .........................................13

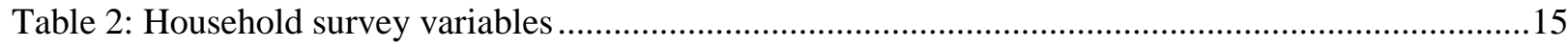

Table 3: Variables characterising urban structure................................................................................. 17

Table 4: Descriptive statistics of the variables used in the econometric analysis ..................................21

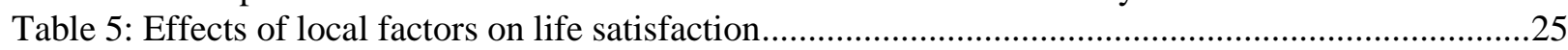

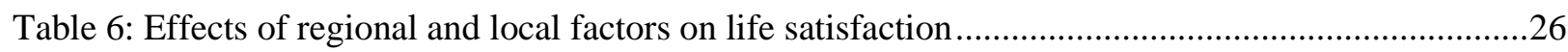

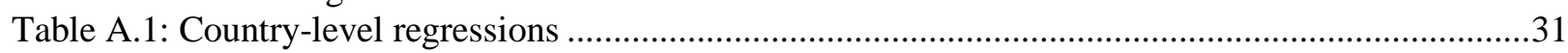

Table B.1: Variance inflation factors (VIF) for survey covariates in the regression analysis ...................32

Table C.1: Sensitivity of regression results to the boundary radius for local environmental variables ......34

\section{Figures}

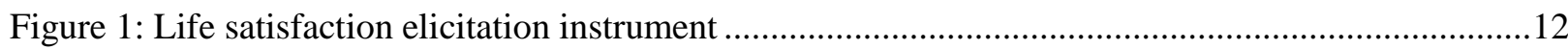

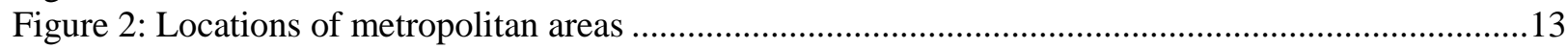

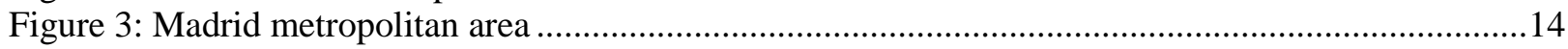

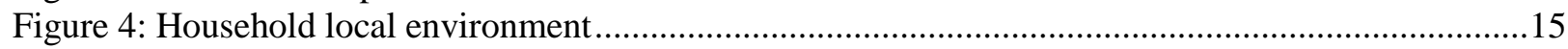

Figure 5: Mean life satisfaction, by city and relative distance to urban core.........................................18

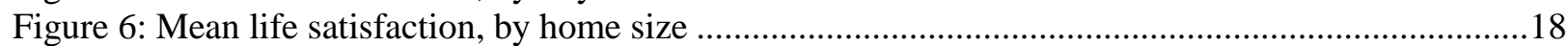

Figure 7: Mean life satisfaction, by population density in the metropolitan area ..................................19

Figure 8: Mean life satisfaction, by local greens space, forests and agricultural land use .......................19 


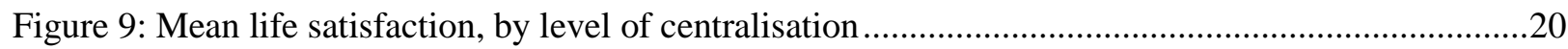

Figure 10: Mean life satisfaction, by land use diversity .....................................................................20

Figure 11: Scatterplot of Shannon Weaver land-use diversity index, by proportion of green space.........21

\section{Boxes}

Box 1: Classifying Functional Urban Areas (FUAs) .12 


\section{INTRODUCTION}

By 2050 , nearly $70 \%$ of the world's population is projected to be living in urban areas (OECD, 2015). Concerns for urban quality of life and its impact on people's welfare are highlighted as a major issue in many cities. Scales and shapes of cities necessarily induce organisational forms that affect the daily lives of residents and, therefore, their welfare. However, conventional welfare measures, such as Gross Domestic Product (GDP), ignore several non-market factors that may explain individual well-being, including quality of life within urban areas.

The measurement of well-being has always been a central topic in economics, but in recent years, a broader perspective to the measurement of well-being is emerging (Deaton, 2008). As part of this broader perspective, there is an increased interest in using subjective well-being of people as a proxy for utility, and therefore an indicator of well-being (often using "happiness" or "life satisfaction"). In addition, many economists include several factors beyond income (such as health, employment, and marital status) to explain the well-being of people (Fleurbaey, 2009; OECD How's Life, 2013). The effect of environmental quality on subjective well-being has also been investigated, as reviewed below.

At the scale of the city, these factors act interdependently on subjective well-being. Concentration of activities in the city is a source of employment and various other market services, but also a place where different (positive and negative) externalities are jointly produced. Thus, it is reasonable to assume that city scale, urban morphology and land-use systems play a non-trivial, if complex, role in determining subjective well-being. Although many factors influence life satisfaction (LS), there is a growing conviction among urban and regional policy makers that the urban structure is one of them (OECD How's Life in Your Region, 2014). Understanding the nature of the relationship between life satisfaction and individuals' direct environment is an essential question that lies at the core of urban planning policies.

In recent years, urban sprawl has become a major public policy issue across OECD countries, reflecting widespread complaints that city growth is paving over landscapes and degrading environmental quality. Many environmental services directly benefit households and could be expected to directly affect life satisfaction. These include clean air, reduced noise and light pollution, as well as close access to forests and parklands. Other environmental services might affect life satisfaction indirectly; for example, a wetland's water filtration services might improve water quality, and thereby indirectly affect health.

In response to these concerns, many cities and national governments have adopted policies to limit sprawl, including various restrictions on development at the urban fringe, new charges levied on builders, and the public purchase of open space. However, the extent to which these measures in fact improve the welfare of inhabitants is not well-known, and here there is scope for empirical investigation. A priori, there is no economic reason to believe that denser cities - or more compact ones - are any more or less welfareimproving for the population as a whole, particularly if we focus on today's populations and set aside the conservation benefits of compact cities for future generations. There are clear trade-offs in different urban structures. Compactness can facilitate commerce and reduce search costs for both goods and services (including employment opportunities), but it can also increase equilibrium housing prices and - depending on municipal infrastructure - congestion.

To address these issues, this paper explores the impact of urban structure on households' well-being. Is there a significant relationship between different urban development patterns and life satisfaction, and what dimensions of the urban patterns are affecting well-being? The answer to this question has obvious 
welfare implications for land-use policies promoting, for example, compact cities. It also has implications for the degree to which local populations will support different land-use policies.

Understanding the relationship between life satisfaction and urban structure is important for the economic success of cities. In recent decades policymakers have become increasingly concerned with the competitiveness of cities, the policy factors that can enhance entrepreneurship and the positive 'agglomeration' benefits that cities provide (Fujita and Thisse, 2013). In this light, understanding how urban planning and local development policies interact with inhabitants' life satisfaction is key to attracting a skilled and creative labour force that fuels cities' competitiveness (Glaeser, Rosenthal and Strange, 2010; Rapport, 2009).

Urban planning is an important component of 'Green Growth' strategies (OECD, 2013) in cities. Life satisfaction indicators complement traditional economic indicators in measuring progress towards green growth. The application of a life satisfaction approach to assess the impacts of urban structure on wellbeing is novel in this regard.

The remainder of the paper is organised as follows. In Section 2 we review the related literature and elaborate the hypotheses underlying this study. Section 3 describes data and discusses methodological issues related to the spatial metrics used to characterise urban structure. Section 4 provides a summary inspection of the data. Section 5 presents the empirical results. Section 6 concludes.

\section{LITERATURE REVIEW}

In the standard monocentric city model, households' decisions about their location - close to the city centre or out in the hinterlands - reflects a balancing of commuting costs (generally increasing with distance from the city centre), real estate prices (per square meter), as well as the amenities provided at any given location. In the literature examining urban sprawl and leapfrog development, the amenities typically focused on are those related to open space. Equilibrium levels of housing prices, demand and development in these models are characterised by an indifference condition - the equalisation of households' utility regarding location choice (Wu and Plantinga, 2003). This utility level, which is either exogenous or endogenous, depending on the modelling framework is nevertheless treated as unobservable.

Most related empirical work on the value of open space (and, to a lesser degree, urban structure) focuses on the hedonic estimation of housing price gradients with respect to the availability of local amenities (e.g. McConnell and Walls, 2005). Due to methodological reasons touched on below, little empirical work has explored the direct measurement of utility itself - or the related construct of life satisfaction - and the marginal effects of amenities, distance and housing size.

As reviewed in the OECD's Guidelines on Measuring Subjective Well-being (2013), life satisfaction is generally the component of overall subjective well-being (SWB) considered most relevant for policy analysis. In measuring life satisfaction, the researcher's aim is to elicit an individual's "cognitive evaluation of their life as a whole (or aspects of it)". In contrast, two other components of SWB - 'affect' and 'eudaimonia' - correspond, respectively, to an individual's current emotional state and to behaviourally observed indicators of 'flourishing' (e.g. goal-seeking, learning and altruistic behaviours). In this sense life satisfaction corresponds most closely to the typically unobserved variable of 'utility' which is the basis for much of classical economic theory (Marshall, 1890). However, there are important 
distinctions between utility, as employed in economic theory and in the psychologist's construct of life satisfaction for individual decision-making (Kahneman and Kruege, 2006). An important distinction between utility theory and life satisfaction approaches is that the former only treats utility as an ordinal measure which need not (and generally cannot) be directly compared between individuals. In contrast, life satisfaction approaches, while sometimes treating the data as ordinal, generally view these measures as cardinal, ${ }^{1}$ and - more importantly - rely explicitly on the interpersonal comparison of stated life satisfaction. The use of life satisfaction approaches for population-level welfare analysis, as an alternative or complement to benefit-costs analysis (BCA), is thus an area of continuing investigation (Adler, 2012).

Beginning essentially with a study using country-level data by Welsch (2002), a growing body of empirical work has investigated the role played by environmental quality in life satisfaction, much of it reviewed by Welsch and Kühling (2009). Generally, air, water and noise pollution have comprised the environmental quality factors most investigated using life satisfaction approaches (see, for example, MacKerron and Mourato, 2009; Rehdanz and Maddison, 2008; Silva, Keulenaer and Johnstone, 2012; Van Praag and Baarsma, 2005). Most recently, Ferreira et al. (2013), using three waves of the European Social Survey spanning 2002 to 2007 and covering 30 European countries, provide arguably the most robust evidence to date that air pollution (measured in their study by $\mathrm{SO}_{2}$ concentrations) significantly degrades life satisfaction. Their results imply, for example, that a $0.5 \mu \mathrm{g} / \mathrm{m} 3$ reduction in $\mathrm{SO}_{2}$ concentrations (approximately equal to a 10\% reduction in the mean concentration levels observed in the researchers' dataset) has the same average effect on life satisfaction as a $2.7 \%$ increase in household income. ${ }^{2}$

Less work has examined the effect of urban development patterns on life satisfaction which is the motivation for the present study. Early public health research in this area focused mostly on the link between urban structure, individual activity levels and health. Frank and Engelke (2001), for example, find a positive link between these factors. A preliminary investigation specifically into the drivers of life satisfaction by Brereton et al. (2008) in Ireland finds evidence that a number of spatial factors play a role in determining life satisfaction. Population density appears positively associated with life satisfaction, as do warmer, less windy climates and proximity to airports and the coast. Proximity to roads is negatively associated with life satisfaction. In a quantitative case study of two communities in Belgium, Van Herzele and de Vries (2012), find some suggestive evidence that green space access positively influences subjective well-being. OECD (2013) proposes a conceptual framework defining well-being as result of individual and place-based characteristics, but does not explicitly use region-level life satisfaction data. In a recent (and as yet unpublished) conference paper, Kopmann (2014) investigates the role of land use on life satisfaction, finding evidence that proximity to forests as well as to a built environment can alternately benefit life satisfaction, depending on the local context. This paper also makes an attempt at constructing an economic model with which to generate testable hypotheses about how land use influences life satisfaction. This attempt, which remains incomplete in the referenced paper, is badly needed in this literature to better interpret identified statistical relationships between life satisfaction and land use.

The above literature motivates the following hypotheses which we test in this study:

- Hypothesis I: Inspired by the monocentric city model in urban economics, we hypothesise that life satisfaction is positively affected by home size and negatively affected by distance to the urban core, controlling for other factors.

\footnotetext{
${ }^{1}$ Though the econometric consequences of cardinal versus ordinal treatment of the data so far appear to be minor in the literature.

2 This type of valuation exercise, in which the regression coefficient estimate associated with the environmental quality attribute of interest is divided by the coefficient associated with income, remains a controversial approach to environmental valuation and is thus not often directly reported in LS studies. Nevertheless, it remains a useful exercise in gauging the measured effect of environmental quality on LS in terms of economically meaningful units.
} 
- Hypothesis II: More green space - forests, farmland, wetlands or urban green space - is generally associated with higher life satisfaction, all other factors being equal.

- Hypothesis III: More diversity in land uses in a household's local vicinity is associated with increased life satisfaction, due to higher accessibility to the wide range of services provided by these land uses (e.g. recreational opportunities, access to different commercial centres, etc...).

- Hypothesis IV: Controlling for congestion (see below), population density has a positive effect on life satisfaction, due to positive agglomeration externalities.

- Hypothesis V: Controlling for agglomeration externalities associated with overall population density, city compactness is negatively associated with life satisfaction due to congestion externalities, particularly for those living in the urban core (and thus experiencing 'compaction').

\section{DATA}

This paper is based on the 2011 round of the OECD Household Survey on Environmental Policy and Individual Change (EPIC), complemented with GIS-based indicators and contextual data from the OECD Metropolitan Database, OECD Functional Urban Areas and European Environmental Agency (EEA).

Details about the survey implementation and descriptive statistics can be found in a previous publication (OECD, 2014b). In brief, nationally representative groups of approximately 1,000 households were sampled for each of the 11 countries involved. Global Market Insight (GMI), a web survey firm, conducted the survey. To obtain nationally representative samples, GMI maintains panels of respondents who receive periodic requests to participate in various web-based surveys. GMI adheres to the ESOMAR 26 guidelines for web-based panel surveys (Callegaro and DiSogra, 2008). Respondents from GMI's panels were invited to participate in the OECD survey using a quota sampling methodology. Using national-level statistical and census data, quotas targets were set for gender, age, household income quintile, and geographic distribution within each country. The completion rate for the survey was greater than $75 \%$ in each of the countries, and all quotas were achieved to within $20 \%$ of their targets, with the exception of the highest income quintiles for some countries. Potential respondents who started the questionnaire were asked whether they met the screening criteria presented above (living in noninstitutional settings and influential in household financial decisions). If they did not meet the criteria, they were thanked for their time and screened out of the sample. The overall drop-out rate was $21 \%$. This varied from $13 \%$ in Korea to $35 \%$ in Chile. Median response times by country varied from 28 minutes (Korea) to 41 minutes (Chile), with the medians in all countries being less than 35 minutes except Chile. In cleaning the data, it was observed that a small fraction of respondents were 'speeders' i.e. these individuals progressed through the survey at such a rapid pace that the validity of their responses is suspect. To address this issue, respondents who completed the questionnaire in less than half of the median response time for their country were removed from the dataset. Data on life satisfaction were elicited using the web-based instrument depicted below. 


\section{Box 1: Classifying Functional Urban Areas (FUAs)}

OECD has developed a harmonised definition of urban areas that reflects the functional connections among places and applied this definition to more than 1,000 urban areas in 28 OECD countries, defining the functional urban areas (OECD 2012 Redefining urban: a new way to measure metropolitan areas), identifying a preliminary set of socioeconomic and environmental indicators to be produced with different methods according to the functional boundaries of urban areas.

The three main steps of this methodology consist in identifying core municipalities through gridded population data, connecting non-contiguous cores belonging to the same functional area and identifying the urban hinterlands.

The methodology uses population grid data at $1 \mathrm{~km}^{2}$ to define urban cores in a way that is robust to cross-country differences in administrative borders. Once the densely inhabited municipalities are aggregated to form urban cores and polycentric metropolitan areas with tied cores are identified, the final step of the methodology consists in delineating the hinterland of the metropolitan areas. The "hinterland" can be defined as the "worker catchment area" of the urban labour market, outside the densely inhabited core.

Among the 1,148 functional urban areas identified in the 28 OECD countries, 74 are large metropolitan areas with more than 1.5 million people, 190 are metropolitan areas, 400 are medium-sized urban areas, and 484 are small urban areas. In this study we use the metropolitan areas.

Recently, OECD and the EU harmonised the nomenclature of the FUAs. "Urban core" is now called "city" while "Hinterland" is now called "commuting zone". Please note this paper use the old nomenclature, in line with the monocentric city model it assumes, while using FUAs which are for some of them polycentric.

\section{Figure 1: Life satisfaction elicitation instrument}

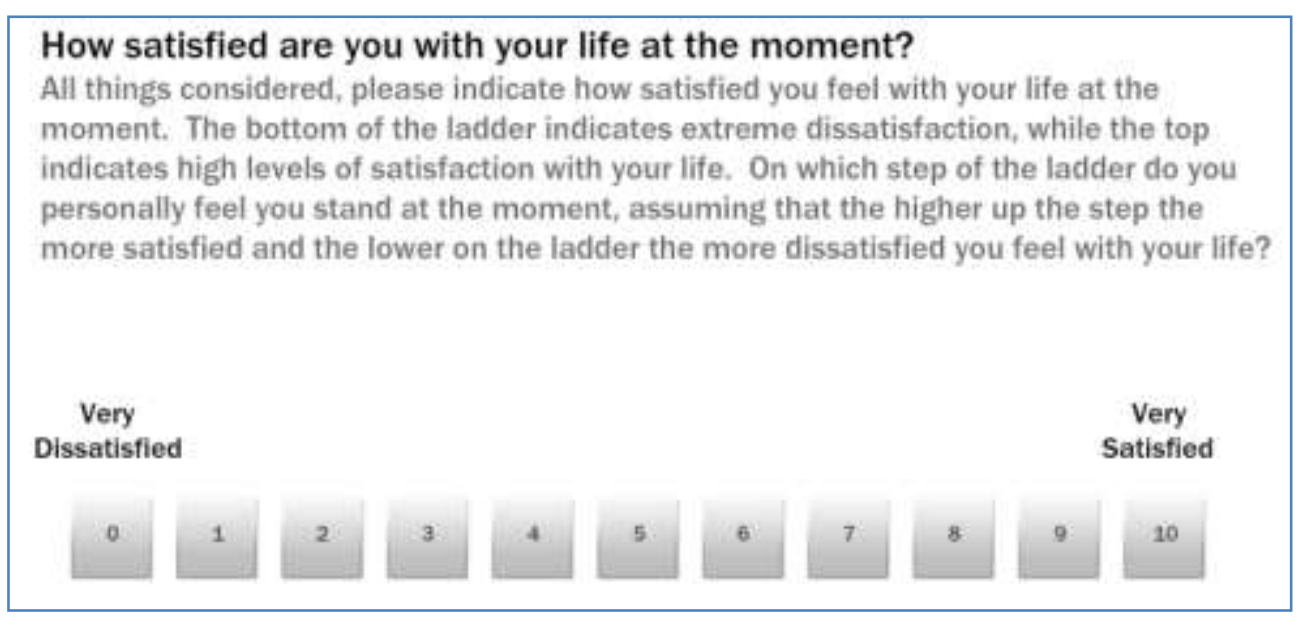

The present analysis is restricted to households living inside Functional Urban Areas for which the economic data is reported in the Metropolitan Database, which means the FUAs of levels 3 and 4 (urban areas with a population above 500 000, called Metropolitan Areas). After merging the various data sources and eliminating FUAs with too few observations (less than 10 surveyed households), the final sample consists of 1,964 households, distributed across 33 cities (FUAs) in 6 countries (Table 1). 
Table 1: Sample sizes in selected countries and in metropolitan areas (MA)

\begin{tabular}{|lllllll|} 
Countries & M. Areas & $\begin{array}{l}\text { National HH } \\
\text { Survey Sample }\end{array}$ & $\begin{array}{l}\text { in M. } \\
\text { Areas }\end{array}$ & Respondents & $\begin{array}{l}\text { M. Areas in our } \\
\text { sample }\end{array}$ & $\begin{array}{l}\text { Respondents in } \\
\text { our sample }\end{array}$ \\
\hline FRANCE & 14 & 1,227 & $43 \%$ & 532 & 12 & 502 \\
\hline JAPAN & 33 & 1,043 & $39 \%$ & 406 & 5 & 290 \\
\hline NETHERLANDS & 5 & 1,301 & $37 \%$ & 478 & 5 & 428 \\
\hline SPAIN & 8 & 1,101 & $41 \%$ & 455 & 8 & 447 \\
\hline SWEDEN & 3 & 1,012 & $30 \%$ & 302 & 3 & 297 \\
\hline TOTAL SAMPLE & 63 & 4,641 & $38 \%$ & 1767 & 33 & 1964 \\
\hline
\end{tabular}

Figure 2: Locations of metropolitan areas

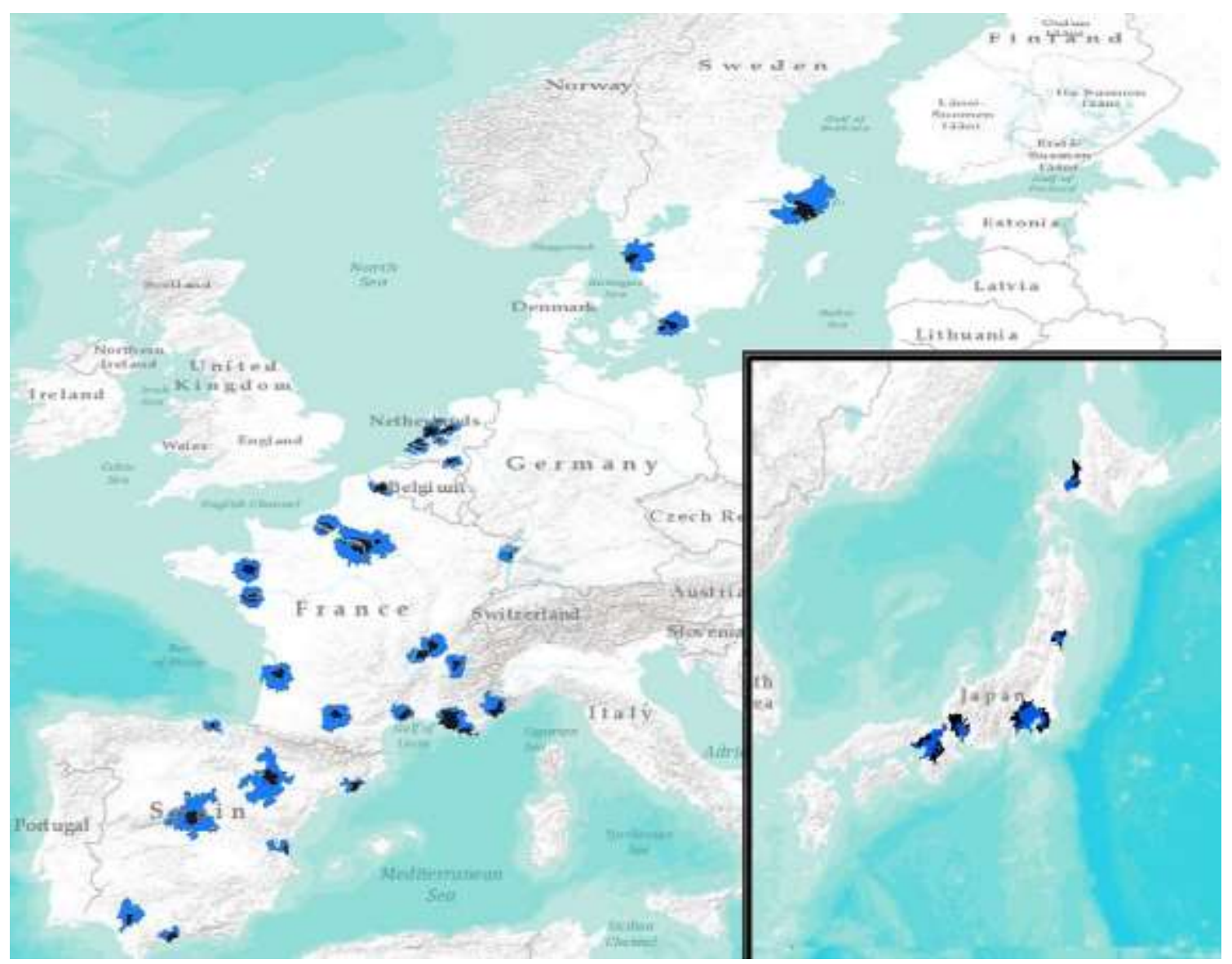

Source: OECD Metropolitan Database

Description: Here are represented OECD Metropolitan Areas for Spain, France, the Netherlands, Sweden and Japan. Black areas are the core of the metropolitan areas, and blue areas represent the hinterlands. 
The OECD Metropolitan Database includes a set of annual variables related to 275 OECD functional urban areas with a population of 500,000 and more ${ }^{3}$. The definition of urban areas in OECD countries uses population density to identify urban cores and travel-to-work flows to identify the hinterlands whose labour market is highly integrated with the cores.

Finally, indicators of composition and diversity of land use are derived from the Corine Land Cover (CLC) database maintained by the EEA for Europe. This database provides consistent information on land cover across Europe. The satellite images are processed to form a map composed of $100 \mathrm{~m} \times 100 \mathrm{~m}$ contiguous cells, which are each coded using the 44 classes. For Japan, both Japanese land use and road network data come from the National Land Numerical Information Service. Using these multiple data sources, two sets of indicators are built reflecting the two levels of household's environment considered here: first, the Functional Urban Area in which the household is located (Figure 3); and second, household's local environment, which is represented by a $5 \mathrm{~km}$ radius around household's location (Figure 4).

\section{Figure 3: Madrid metropolitan area}

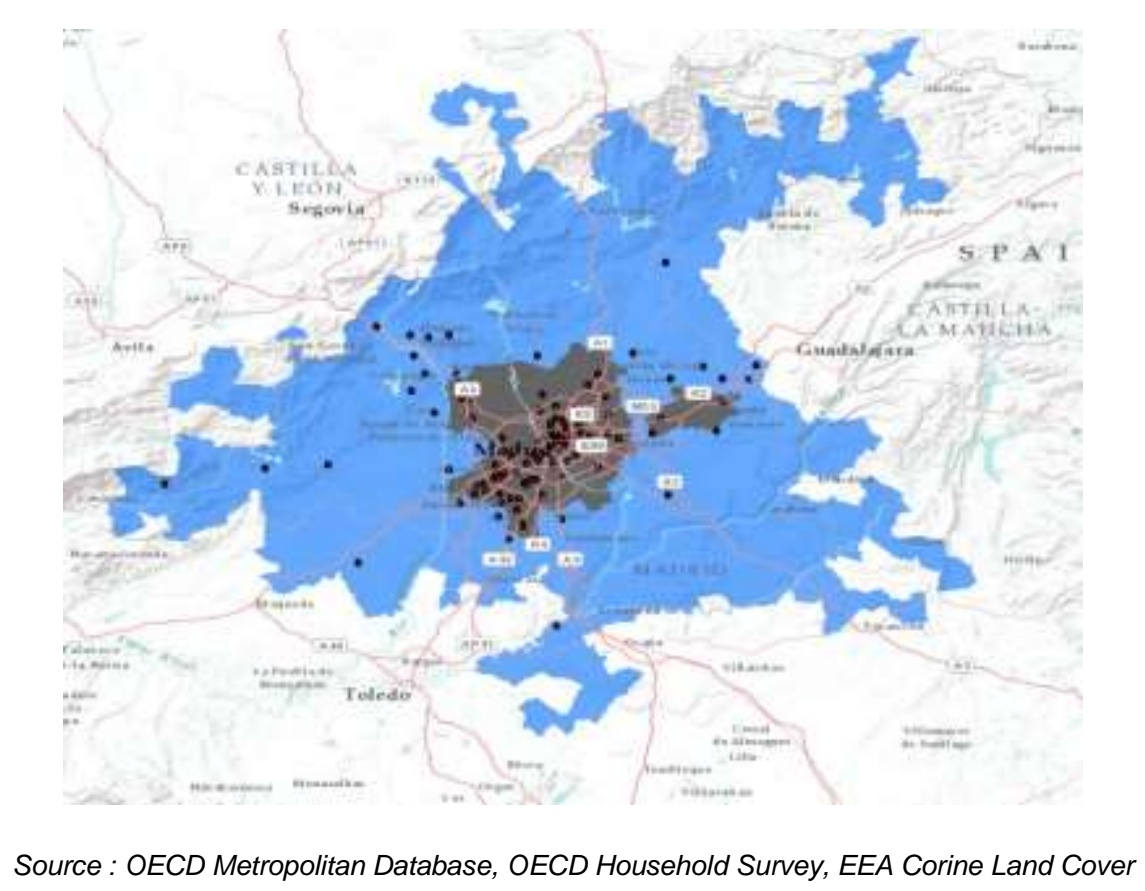

Description: Here is represented the Metropolitan Area of Madrid, Spain. Black dots represent the positions of the households as being the centres of their postal codes. The High speed Road Network used to calculate road densities is represented with red line.

\footnotetext{
${ }^{3}$ It is publicly available at: http://measuringurban.oecd.org/.
} 
Figure 4: Household local environment

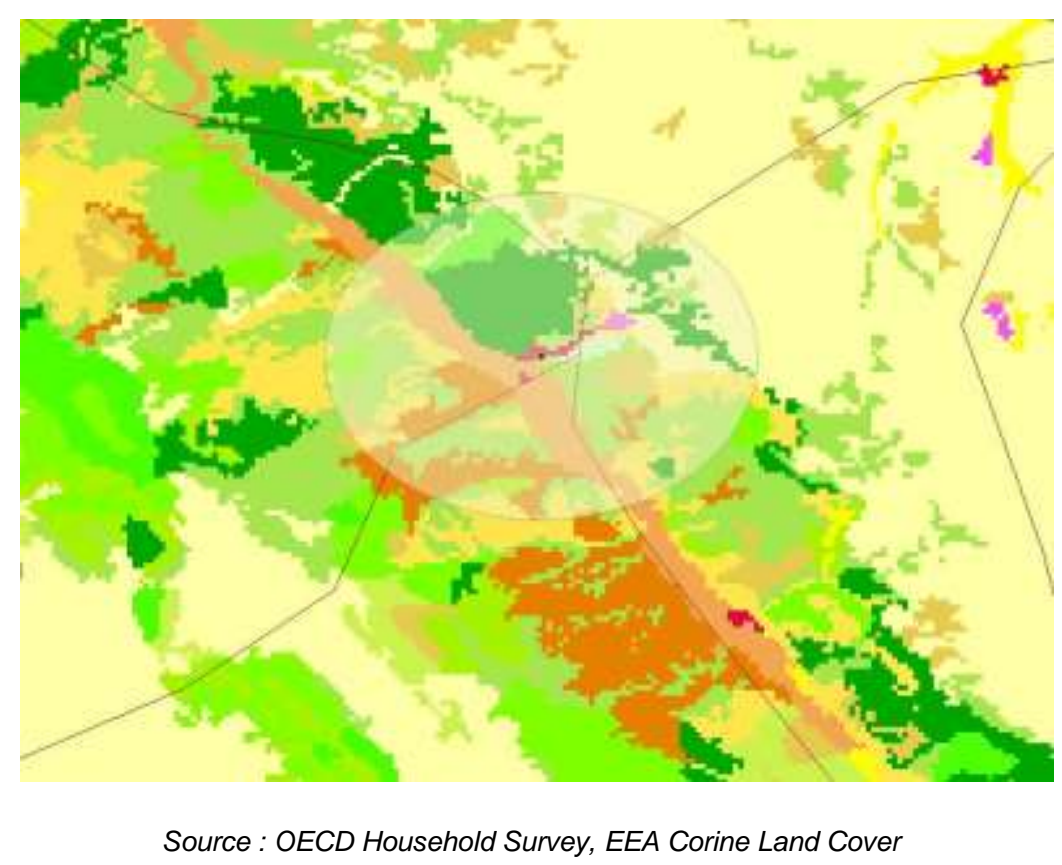

Description: Here is a zoom on a household in the Region of Madrid, Spain. The circle represents the $5 \mathrm{~km}$ radius around the household position in which the local variables of land use are calculated. The map is constituted by the Corine Land cover $100 \mathrm{~m} x$ $100 \mathrm{~m}$ cells where colours represents their classes (yellow is crops, green is forest, etc.). Red lines represent the High Speed Roads Network.

\section{Individual characteristics}

The household survey provides basic information on the individual characteristics largely used in well-being literature as main drivers of life satisfaction (as indicated in the above literature review). These variables, related to demographics, health, household structure, and financial well-being, are listed in Table 2. In particular, note that the survey collects data on households' home sizes, which while not being measured via GIS or administrative data, is certainly related to urban structure. This allows us to test Hypothesis I above.

\section{Table 2: Household survey variables}

\begin{tabular}{ll}
\hline VARIABLES & Description \\
\hline Age & Age of respondent, in years. \\
Female & Binary variable taking a value of 1 if respondent is female, and 0 otherwise. \\
Married & Binary variable taking a value of 1 if respondent is married, and 0 otherwise \\
Young child & Binary variable taking a value of 1 if young children are present in the household, 0 otherwise. \\
Income & Per capita annual income, in 2007 euros. \\
Post-secondary ed. & Number of years of post-secondary education that the respondent completed. \\
Unemployed & Binary variable taking a value of 1 if respondent is unemployed and 0 otherwise. \\
Medical conditions & $\begin{array}{l}\text { Number of medical conditions stated to be present in the household, divided by the number of household } \\
\text { members }\end{array}$ \\
Home owner & Binary variable taking a value of 1 if the household owns their home. \\
Home size & Size of residence, in square meters $\left(\mathrm{m}^{2}\right)$. \\
\hline
\end{tabular}




\section{Urban structure indicators}

Our approach to link individual life satisfaction with urban structure is to decompose the individuals' environment in two levels. The first level is the direct environment surrounding the place of living of the respondent. The second (higher) level is the metropolitan area in which the respondent lives. In this paper, any references to cities formally means the metropolitan area, a definition which provides comparable territorial and functional units in which individuals live, work and access amenities, develop social relations, etc...

Table 3 describes the urban structure variables that are used in the analysis. We divide these variables into local factors, which vary at the household level, and regional factors which vary at the city level. Local factors include a household's distance to the city centre, as well as factors related to land use. Specific land use factors include the proportion of land within a $5 \mathrm{~km}$ radius around the household's postal code centroid which is 'green', i.e. devoted to agricultural, forestland or urban green spaces. ${ }^{4}$ This allows us to test Hypothesis II.

As per Hypothesis III, we also include a measure of land use diversity, again corresponding to a $5 \mathrm{~km}$ radius around each household in the sample. Throughout the paper we use the Shannon-Weaver entropy measure of diversity (Torrens, 2008). This defines the land use diversity $V_{i}$ around household $i$ as:

$$
V_{i}=\sum_{j}-p_{i j} \log p_{i j}
$$

where $p_{i j}$ is the fraction of land within a $5 \mathrm{~km}$ radius around household $i$ 's postal code centroid which corresponds to land use $j .{ }^{5}$ This index ranges from zero (when all land around the household is associated with a single use) to $\log M$, where $M$ is the total number of land uses considered and corresponding to a situation where land around the household is evenly distributed across all uses considered. ${ }^{6}$ Of course, being based on the same underlying data as the 'green space' variable, a strong relationship (if not a linear correlation) would be expected between this diversity index and the green space variable. (In fact, there is an inverse U-shaped relationship between the two variables, as shown in Figure 11 in the next section).

\footnotetext{
${ }^{4}$ We experimented with alternative specifications for this variable, including water and wetland 'land' uses. These specifications were never found to affect the results presented below.

5 A number of other possible diversity indices were explored, such as the Simpson, inverted Simpson and SIEI indices. All of these indices, being constructed from the same underlying data, are highly correlated and yield similar results in the econometric estimation.

${ }^{6}$ Seven exhaustive and mutually exclusive land use classifications are measured in our dataset: Agriculture, forests, wetlands, water, artificial, 'urban fabric' and 'green urban.' Thus, the maximum value of the ShannonWeaver diversity index here is $\ln 7 \approx 1.94$.
} 
ENV/WKP(2015)16

Table 3: Variables characterising urban structure

\begin{tabular}{lll}
\hline VARIABLES & DESCRIPTION & SOURCE \\
\hline Regional (City-level) & ${ }^{2}$ & \\
Size - City population & Total population of the FUA in 2011 & MD \\
Density of Roads & $\begin{array}{l}\text { High Speed Roads Km (2012 for Europe, 2011 for } \\
\text { Japan)/ Surface of the FUA }\end{array}$ & GIS \\
Density - City Population Density & Population of the FUA / Surface of urbanised area & MD/GIS \\
Centralisation & Population of the core / Population Hinterlands & MD \\
Local (household-level) & These variables are computed in the local environment of & \\
Distances to the core & $\begin{array}{l}\text { Households ( } 5 \mathrm{~km} \text { radius) } \\
\text { Chortest distance to the boundary of the core (kilometres) }\end{array}$ & GIS \\
Shannosition of local environment & $\begin{array}{l}\text { Proportion of urban fabric \& artificial surfaces within the } \\
\text { radius of } 5 \text { km around ZIP code centroid. }\end{array}$ & GIS \\
\hline
\end{tabular}

${ }^{1}$ [MD : OECD Metropolitan Database / GIS : Computed using ArcGIS 12 ]. ${ }^{2}$ FUA = Functional Urban Area

\section{DESCRIPTIVE STATISTICS}

With respect to our hypotheses, summary inspection of the data reveals some robust patterns in the data, as well as many questions for econometric analysis. First, with respect to Hypothesis I, the relationship between life satisfaction and distance to the urban core reveals no clear relationship (Figure 5), whereas larger homes are clearly associated with higher life satisfaction (Figure 6). ${ }^{7}$ Of course, these factors need to be investigated simultaneously, given the trade-off between city centre closeness and home size. (The correlation between home size and distance to the city centre is 0.25 .) With respect to Hypothesis IV, Figure 7 shows no obvious relationship between population density and life satisfaction. Similarly, Figure 8 provides little evidence to support Hypothesis II that nearby green spaces around the household are associated with greater life satisfaction. With respect to Hypothesis V, a relatively robust pattern emerges with respect to centralisation in Figure 9; the greater the share of the city's population which is in the urban core, the lower the average level of life satisfaction in the city. However, this figure also shows a distinct difference in the trends in Europe as compared to Japan, with Europe showing a greater range of life satisfaction, centralisation and a corresponding steeper trend line, whereas the Japanese cities in the sample exhibit uniformly lower life satisfaction and centralisation. In Figures 10 and 11, we find little evidence for a relationship between land-use diversity (as measured via the ShannonWeaver index) and life satisfaction (Hypothesis III). Last, Table 4 presents the descriptive statistics of the variables used in the econometric analysis.

\footnotetext{
${ }^{7}$ For locally varying factors such as distance to urban core, we construct figures in this section for the largest sampled metro areas for each of the five countries analysed.
} 
Figure 5: Mean life satisfaction, by city and relative distance to urban core

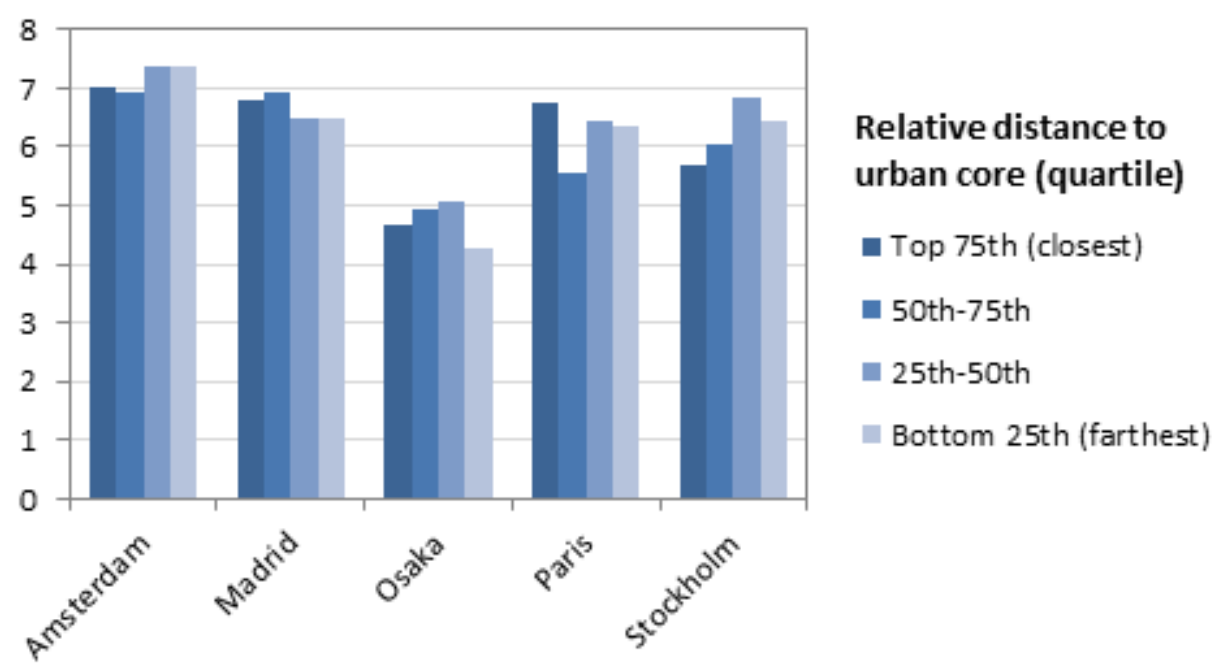

Figure 6: Mean life satisfaction, by home size

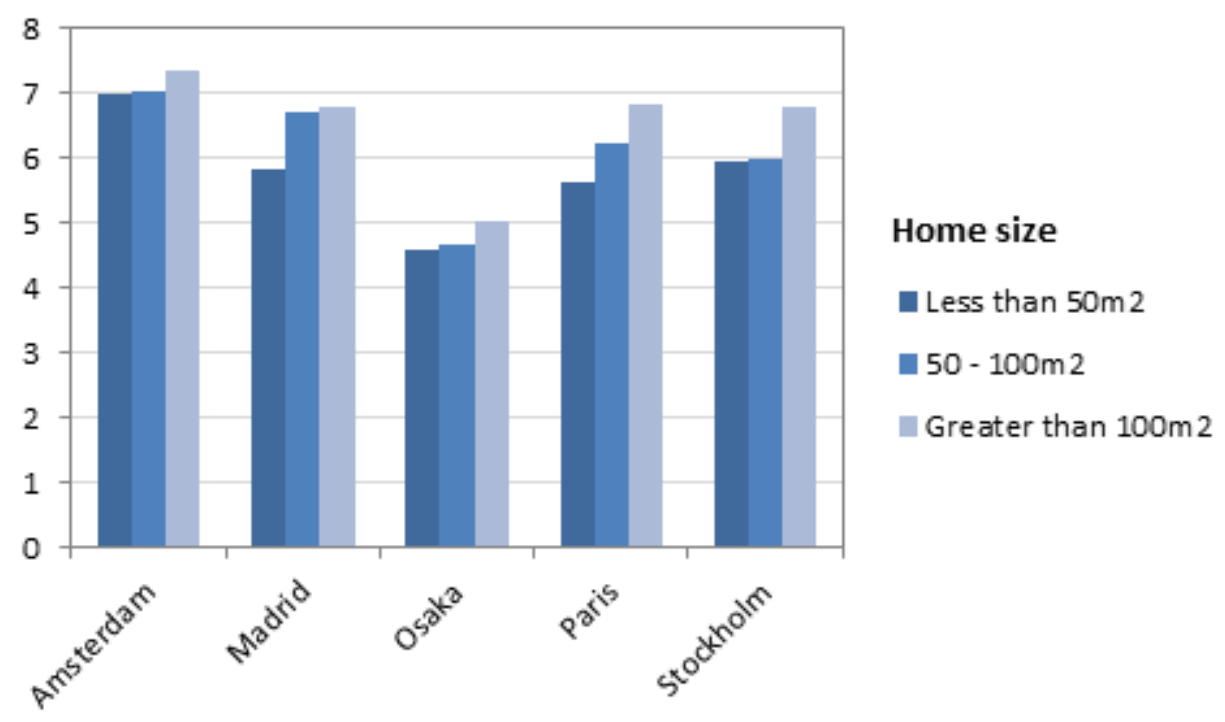


Figure 7: Mean life satisfaction, by population density in the metropolitan area

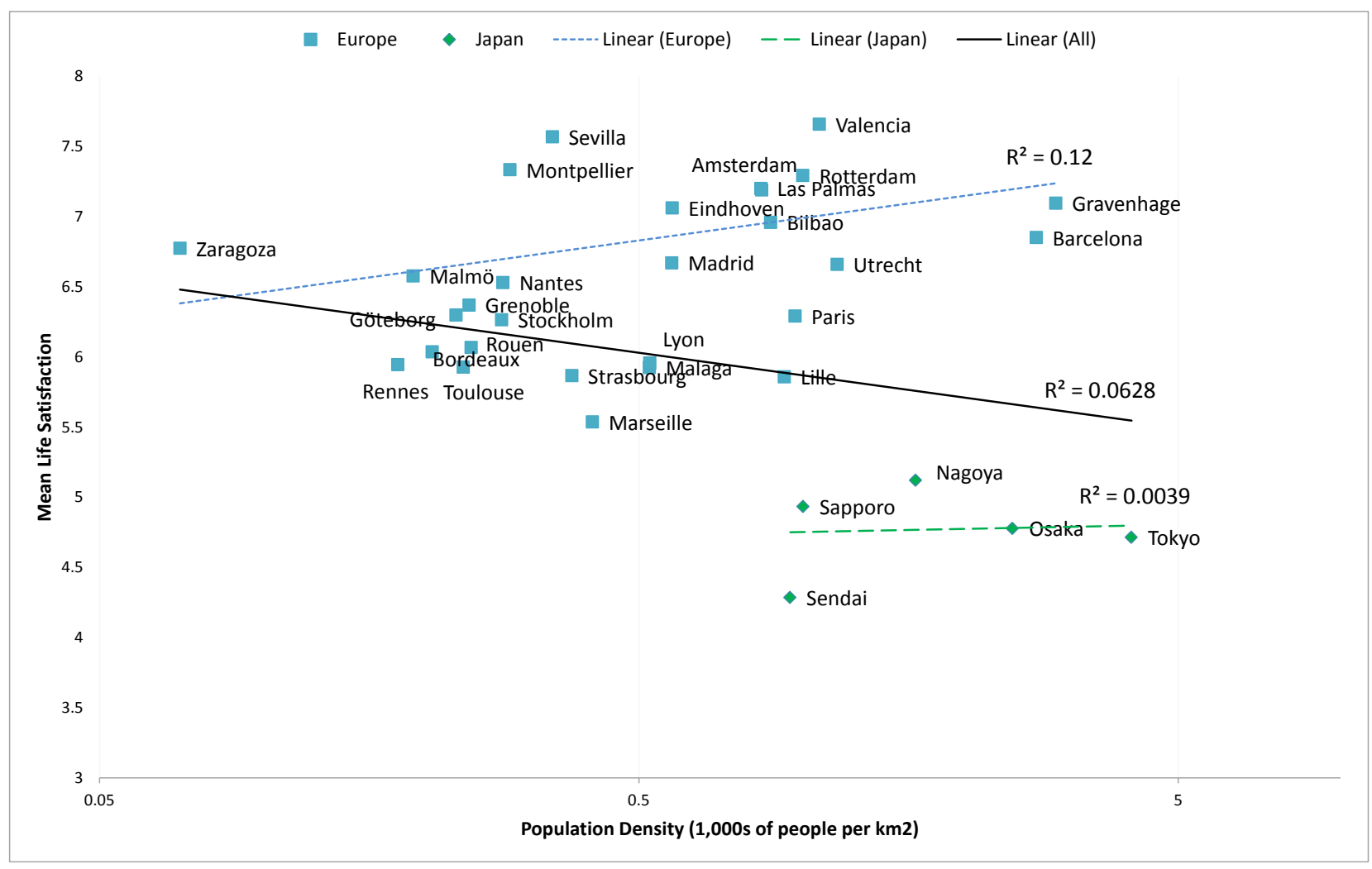

Figure 8: Mean life satisfaction, by local greens space, forests and agricultural land use

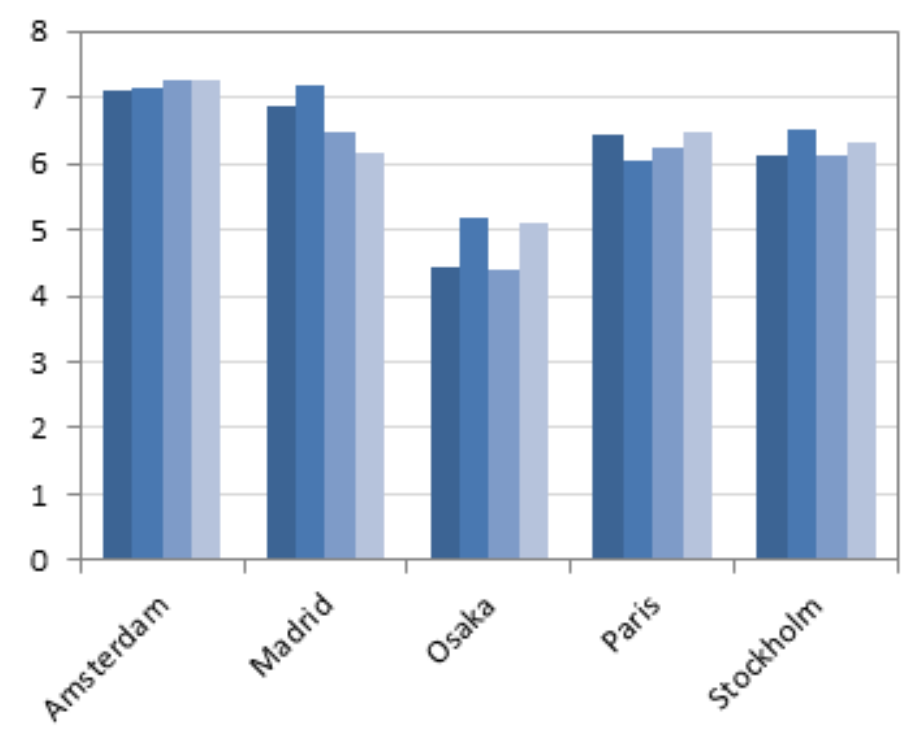

Relative green space, forests and agriculture within $5 \mathrm{~km}$ of household (quartile)

- Bottom 25th

- 25th-50th

50th-75th

- Top 75th 
Figure 9: Mean life satisfaction, by level of centralisation

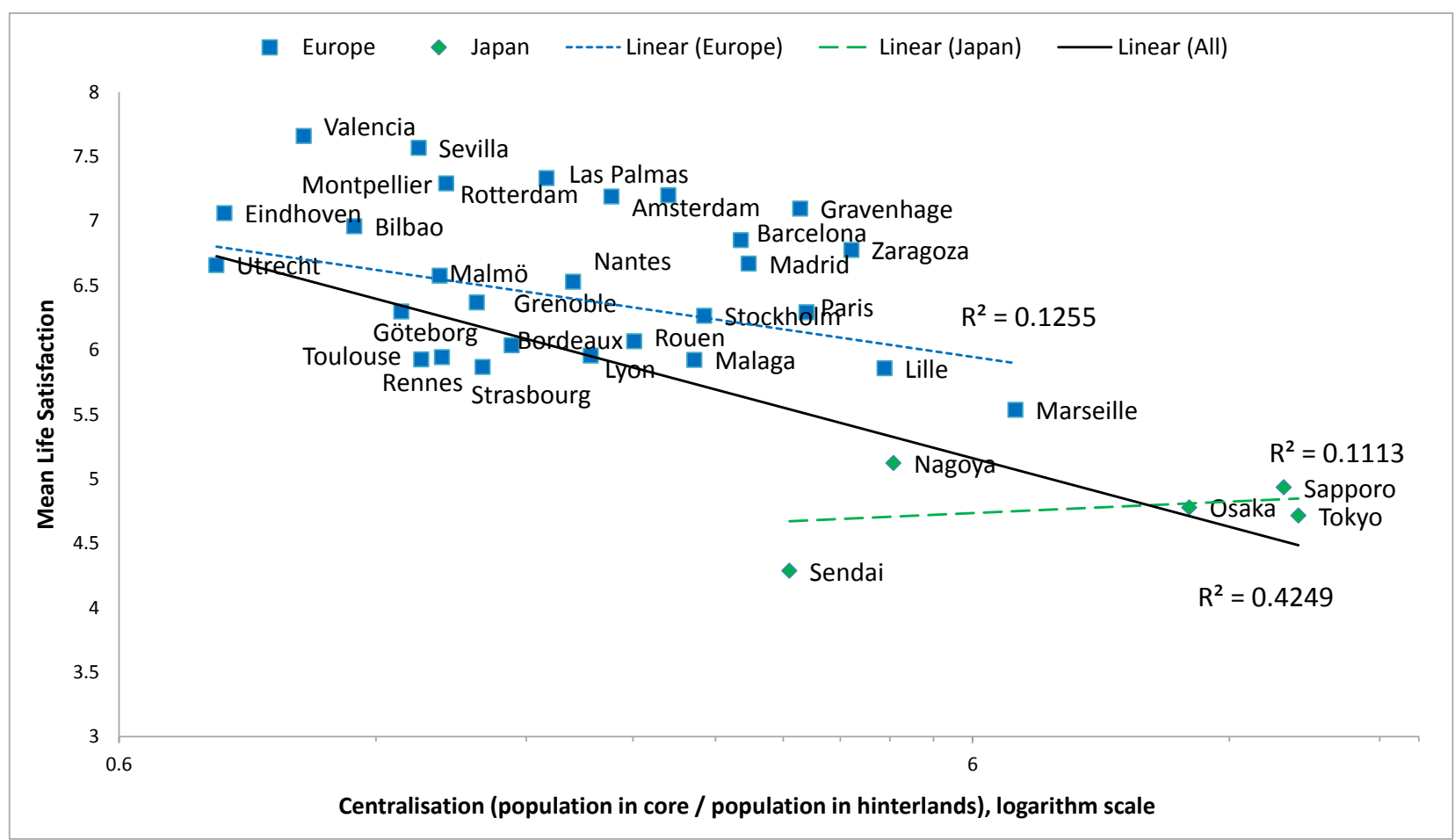

Figure 10: Mean life satisfaction by, land use diversity

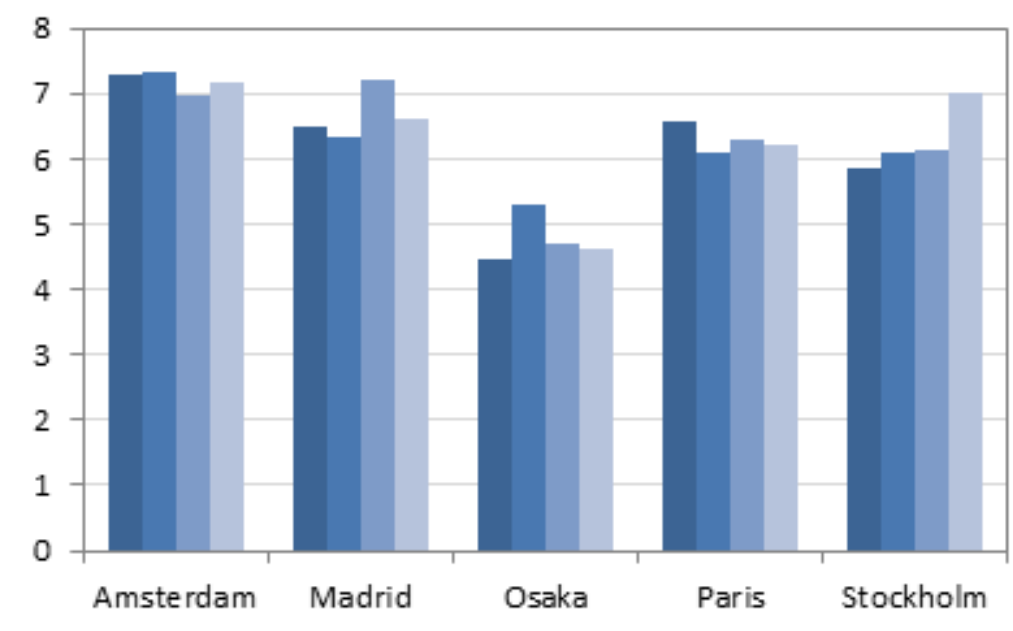

Relative

Shannon-Weaver

index (quartile)

- Bottom 25th

(least diverse)

-25th-50th

w0th-75th

Top 75th

(most diverse) 
Figure 11: Scatterplot of Shannon Weaver land-use diversity index, by proportion of green space

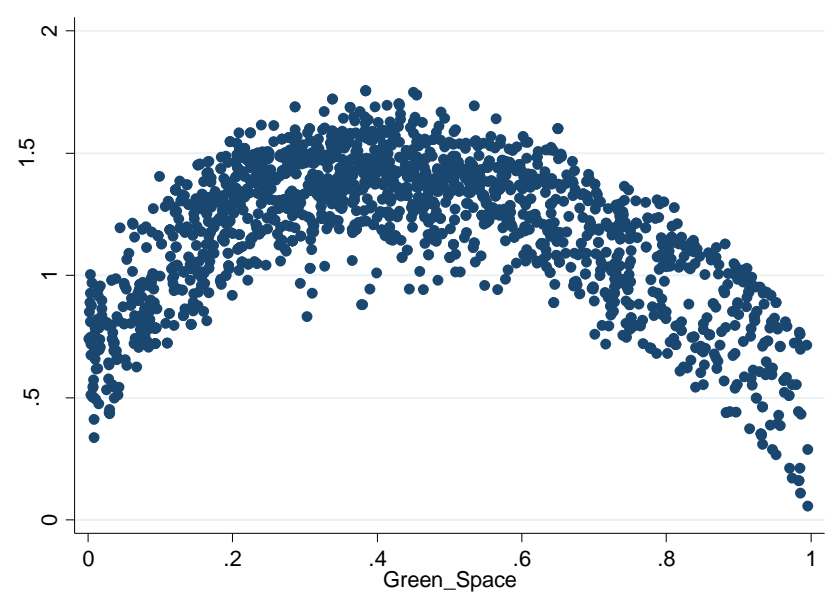

Table 4: Descriptive statistics of the variables used in the econometric analysis

\begin{tabular}{|c|c|c|c|c|}
\hline VARIABLES & Mean & $\begin{array}{l}\text { Std. } \\
\text { Deviation }\end{array}$ & Min & Max \\
\hline Male & 0.51 & - & 0 & 1 \\
\hline Age & 44.24 & 13.29 & 18 & 69 \\
\hline Years of post-secondary education & 3.70 & 3.23 & 0 & 12 \\
\hline Married & 0.57 & - & 0 & 1 \\
\hline Children & 0.34 & - & 0 & 1 \\
\hline Unemployed & 0.08 & - & 0 & 1 \\
\hline Medical conditions per person & 1.66 & 2.02 & 0 & 22 \\
\hline Home owner & 0.65 & - & 0 & 1 \\
\hline Home size $\left(\mathrm{m}^{2}\right)$ & 100.26 & 50.02 & 36.29 & 264.04 \\
\hline $\log ($ Income ) & 10.47 & 0.51 & 9.06 & 11.71 \\
\hline \multicolumn{5}{|l|}{ Local spatial variables } \\
\hline Land-use diversity (index) & 1.20 & 0.29 & 0.06 & 1.75 \\
\hline Green space (fraction within $5 \mathrm{~km}$ ) & 0.44 & - & 0 & 1 \\
\hline \multicolumn{5}{|l|}{ Relative distance to urban core } \\
\hline Top quartile (closest) & 0.27 & - & 0 & 1 \\
\hline 2nd quartile & 0.24 & - & 0 & 1 \\
\hline 3rd quartile & 0.26 & - & 0 & 1 \\
\hline 4th quartile (farthest) & 0.24 & - & 0 & 1 \\
\hline \multicolumn{5}{|l|}{ Regional, metro-level variables } \\
\hline Density $\left(1,000\right.$ s of people $\left./ \mathrm{km}^{2}\right)$ & 1.12 & 1.02 & 0.07 & 4.10 \\
\hline $\begin{array}{l}\text { Centralization (core pop. / } \\
\text { hinterlands pop.) }\end{array}$ & 3.82 & 3.43 & 0.78 & 14.46 \\
\hline Density of Roads (1/km) & 2074.54 & 5028.24 & 0 & 15528.8 \\
\hline
\end{tabular}




\section{ECONOMETRIC ANALYSIS}

To identify the marginal effects of the variables of interest on life satisfaction, we estimate a regression equation of the following form:

$$
L S_{i f c}^{*}=X_{i f c} \beta+Z_{i f c}^{L} \gamma^{L}+Z_{f c}^{R} \gamma^{R}+\eta_{f c}+\epsilon_{i f c}
$$

Here, $L S_{i f c}^{*}$ is the latent (not directly observed) life satisfaction for respondent $i$ in city $f$ and country $c$. The survey instrument uses an 11-point Likert scale as an ordinal indicator for underlying life satisfaction (Figure 1). We therefore use an ordered probit model for this regression, which treats the error term $\epsilon_{i f c}$ as following a standard normal distribution. This means that the coefficients from different specifications of the regression cannot be directly compared with one another (i.e. across columns of the regression tables), due to potential scale differences (Greene, 2003). However, the relative magnitudes of the coefficients can be compared both within and across regressions. In the text we therefore discuss the regression results in terms of 'income equivalent units', i.e. we discuss the coefficient estimates in terms of the percentage change in income that would have the same effect on life satisfaction as the factor of interest (Powdthavee, 2008).

The other terms in the regression are as follows: $X_{i f c}$ is a matrix of standard individual control variables (e.g. age, age squared, gender, employment status, income, etc...), following previous studies (Ferreira et al., 2013; Silva, Keulenaer and Johnstone, 2012; MacKerron and Mourato, 2009; Brereton, Clinch and Ferreira, 2008). The matrix $Z_{\text {if } c}^{L}$ is a set of locally varying spatial variables: green space as a fraction of the land within $5 \mathrm{~km}$ of the household (based on postal code), land-use diversity for land within the $5 \mathrm{~km}$ of the household and relative distance to the urban core (calculated using quartiles of each city's sample). The matrix $Z_{f c}^{R}$ contains indicators of urban structure at the city level: population density, centralisation and road density, as defined above. Of course, these indicators only vary at the level of the city and therefore cannot be combined with city-level fixed effects in a regression, due to collinearity. The associated vectors $\beta, \gamma^{L}$ and $\gamma^{R}$ are vectors of life satisfaction effects to be estimated.

The effect $\eta_{f c}$ captures country- and city-level effects which may be fixed or random. Here, a Hausman test implies that decomposing the effect into a fixed country-level effect and a random city-level effect is the most statistically appropriate model. That is, $\eta_{f c}=\alpha_{f}+\iota_{c}$, where $\alpha_{f}$ varies randomly across cities, following a normal distribution with mean zero and a variance to be estimated, and $\iota_{c}$ is directly estimated for each country $c$.

Table 5 presents estimation results focusing only on the role played by local factors in life satisfaction. The first column ("SES only") estimates a regression focusing only on the factors available in the survey, i.e. the variables in $X_{i f c}$ and their estimated effects $\beta$. Note that this baseline specification includes the variable 'home size,' as this was elicited in the survey (Table 2). Most of the estimated effects in this baseline regression confirm previous findings in the literature. Age exhibits a U-shaped relationship with life satisfaction, with an average respondent's life satisfaction reaching a minimum at around 45 years of age. Unemployment is associated with a large negative impact on life satisfaction, as is poor health (measured as the number of health conditions per person - ranging from cancer to allergies - reported by each respondent). As per Hypothesis I, home size is positively related to life satisfaction, with an increase of $10 \mathrm{~m}^{2}$ in home size having an equivalent average impact on life satisfaction as a $2 \%$ increase in income. It is striking - but not at odds with previous literature (e.g. Brereton, 2008) - that individuals' 
postsecondary education and presence of children in the household has a statistically insignificant effect on life satisfaction (and that the direction of the effect is negative). Indeed, many of the effects (or lack thereof) of the control variables on life satisfaction found here themselves comprise important research topics in their own right. Factors that may be positively associated with life satisfaction, such as marriage or the presence of children, have been found in analysis using panel data to have only transient effects on well-being, which has motivated research into the existence of 'hedonic treadmills' (e.g. Bottan and Truglia, 2011). Potential concerns about multicollinearity were also investigated through analysis of the variance inflation factors or VIFs (Greene, 2003). The maximum VIF was 1.82 , well below any of the thresholds typically recommended as indicating multicollinearity (see Appendix B, Table B.1 for details). Regarding the overall goodness-of-fit of the regression, the generalised R-squared for this and subsequent regressions in the analysis is comparable to other studies (e.g. Brereton, 2008; Powdthavee, 2008), bearing in mind the differences in sample sizes (the present analysis using a sample size between the Brereton and Powdthavee studies) ${ }^{8}$

The last four columns of Table 5 present results for regressions including the local urban structure factors in the matrix $Z_{\text {ifc }}^{L}$ with associated effects vector $\gamma_{L}$. These columns explore the potential effects and confounding of local green space levels and land use diversity, and aim to identify the appropriate specification. As discussed above - and shown in Figure 10 - the land-use diversity index and the green space variables, being composed of the same underlying land-use data, exhibit an inverted U-shaped relationship and can pose potential problems of interpreting estimated coefficients associated with each of these variables.

The regressions in columns (a), (b) and (c) in Table 5 consecutively include both land-use diversity and green space, land-use diversity only, and green space only. Comparison of these regressions shows that the green space variable does not appear to have any explanatory value in the regressions, and simply adds noise. Its coefficient changes dramatically, switching signs, when land-use diversity is either included as well or dropped. Thus, it seems we can find no evidence in the present data that more local green space increases life satisfaction (Hypothesis II); a number of methodological issues surrounding this result deserve attention and are addressed at the end of this paper.

In contrast, land-use diversity appears to have much more explanatory power, but its effect is opposite of that hypothesised. Greater diversity in nearby land-use is associated with a significantly negative effect on life satisfaction - opposite of what was argued in Hypothesis III. Moreover, the estimated effect is quite strong and robust across multiple specifications. The effect of moving from the $25^{\text {th }}$ to the $75^{\text {th }}$ percentile in neighbourhood land-use diversification has an equivalent effect on an average household's life satisfaction as a $15 \%$ decrease in income. This is quite a large effect and one which is clearly worth probing in more detail, though it is difficult to do so with the present data.

A household's distance to the city centre appears to have some effect on life satisfaction, though only at farther distances from the city centre (where the effect is negative). The estimated effect on LS of being in the bottom city-level quartile in terms of distance to the city centre (bottom being the farthest away) is equivalent to the estimated effect of a $25 \%$ decrease in household income. However, this effect is only statistically significant when the green space variable is excluded from the analysis (as we argue it should be, given that the green space variable only seems to introduce noise into the regression). Thus we find some limited evidence to support Hypothesis I related to the monocentric city model, and the trade-off

${ }^{8}$ The Nagelkerke, Cragg, and Uhler formula is used here, which is: "R $\mathrm{R}^{2}=\left[1-\left(\frac{\bar{L}_{0}}{\bar{L}}\right)^{2}\right] /\left[1-\bar{L}_{0}{ }^{2}\right]$, where $\bar{L}_{0}$ is the geometric mean likelihood for an appropriately specified null model (i.e. including fixed or random effects) and $\bar{L}$ is the geometric mean likelihood for the model in question. This formula has the advantage of coinciding with the standard $\mathrm{R}^{2}$ when both are computable. 
between distance to the city centre and home size in a life satisfaction framework. In general, however, the life satisfaction effects of distance to the city centre are likely to be quite heterogeneous across cities, due the large variation in amenities and employment opportunities available in the city centre and hinterlands of each city.

In general, the introduction of land-use diversity and city centre distance appears to increase the explanatory power of the regression by $4 \%$, from a generalised $\mathrm{R}^{2}$ of 0.0969 in the baseline specification to a generalised $R^{2}$ of 0.101 when these local urban structure factors are included.

The final column (d) in Table 5 brings us to a discussion of inter-city variation in life satisfaction, and the potential impacts of city-level factors. This regression includes city-level fixed effects, instead of random effects as in the previous three regressions. Examining the generalised $\mathrm{R}^{2}$ of 0.125 here, we see that city-level factors could increase the explanatory power of the regression by a maximum of $28 \%$. Furthermore, we see that the estimated coefficients on the other explanatory variables do not change appreciably, suggesting that our specification is robust.

Table 6 presents results from regressions which account for city-level factors of urban structure which are hypothesised to predict life satisfaction. The first regression column here simply replicates the baseline specification from Table 5, for ease of reference. The last three columns explore the effects of population density, centralisation and road density on life satisfaction (corresponding to Hypotheses IV and V). The results generally mirror those in Figures 6 and 8: Population density does not determine life satisfaction in a statistically significant way (though the coefficient estimated in Table 5 suggests a positive effect of density on life satisfaction, in contrast to Figure 6). City compactness - the ratio of the population living in the core city to the population outside - is a significant, negative determinant of life satisfaction. As with land-use diversity, the reasons behind this effect would certainly be worth exploring in more detail, though additional data would be necessary to do so.

In general, city-level factors examined here increase the explanatory power of the regression by an additional $1.2 \%$, far less than the potential inter-city variation in life satisfaction. Indeed, a number of other city-level factors were explored in these regressions (not shown here), none of which provided significant explanatory power. ${ }^{9}$ There thus seems to be an important empirical question to be explained in future analysis: what are the largest drivers of inter-city variation in life satisfaction?

\footnotetext{
${ }^{9}$ These additional indicators included indices of 'leapfrog' development (scattering), growth in the urban area, citylevel unemployment, and alternative congestion measures.
} 
ENV/WKP(2015)16

Table 5: Effects of local factors on life satisfaction

\begin{tabular}{|c|c|c|c|c|c|}
\hline & \multirow{2}{*}{ SES only } & \multicolumn{4}{|c|}{ SES + local variables } \\
\hline & & (a) & (b) & (c) & (d) \\
\hline \multirow[t]{2}{*}{ Male } & -0.00312 & 0.00207 & 0.000831 & -0.000511 & -0.00546 \\
\hline & $(0.0461)$ & $(0.0457)$ & $(0.0451)$ & $(0.0455)$ & $(0.0485)$ \\
\hline \multirow[t]{2}{*}{ Age } & $-0.0537^{\star * *}$ & $-0.0536^{* * *}$ & $-0.0536^{\star * *}$ & $-0.0532^{* * *}$ & $-0.0547^{\star \star *}$ \\
\hline & $(0.00903)$ & $(0.00913)$ & $(0.00918)$ & $(0.00899)$ & $(0.0124)$ \\
\hline \multirow[t]{2}{*}{$\mathrm{Age}^{2}$} & $0.000597^{\star \star *}$ & $0.000594^{* * *}$ & $0.000596^{\star * *}$ & $0.000591^{* * *}$ & $0.000609^{* \star *}$ \\
\hline & $(9.6 e-05)$ & $(9.6 e-05)$ & $(9.7 e-05)$ & $(9.5 e-05)$ & $(0.00014)$ \\
\hline \multirow{2}{*}{ Years of post-secondary education } & -0.00135 & -0.00203 & -0.00183 & -0.00187 & -0.00190 \\
\hline & $(0.00564)$ & $(0.00583)$ & $(0.00574)$ & $(0.00577)$ & $(0.00742)$ \\
\hline \multirow[t]{2}{*}{ Married } & 0.0487 & 0.0505 & 0.0508 & 0.0531 & 0.0649 \\
\hline & $(0.0711)$ & $(0.0728)$ & $(0.0729)$ & $(0.0723)$ & $(0.0561)$ \\
\hline \multirow[t]{2}{*}{ Children } & -0.0503 & -0.0460 & -0.0465 & -0.0467 & -0.0590 \\
\hline & $(0.0588)$ & $(0.0586)$ & $(0.0586)$ & $(0.0582)$ & $(0.0583)$ \\
\hline \multirow[t]{2}{*}{ Unemployed } & $-0.364^{\star \star \star}$ & $-0.358^{\star \star *}$ & $-0.360^{\star \star \star}$ & $-0.356^{\star \star \star}$ & $-0.373^{\star * \star}$ \\
\hline & $(0.119)$ & $(0.119)$ & $(0.119)$ & $(0.121)$ & $(0.107)$ \\
\hline \multirow[t]{2}{*}{ Medical conditions per person } & $-0.0485^{\star \star *}$ & $-0.0496^{\star \star *}$ & $-0.0497^{\star \star \star}$ & $-0.0492^{\star * *}$ & $-0.0520^{\star \star \star}$ \\
\hline & $(0.0101)$ & $(0.0101)$ & $(0.0101)$ & $(0.0100)$ & $(0.0132)$ \\
\hline \multirow[t]{2}{*}{ Home owner } & $0.127^{\star *}$ & $0.134^{* *}$ & $0.131^{* *}$ & $0.133^{* *}$ & $0.124^{* *}$ \\
\hline & $(0.0584)$ & $(0.0597)$ & $(0.0602)$ & $(0.0600)$ & $(0.0560)$ \\
\hline \multirow[t]{2}{*}{ Home size $\left(m^{2}\right)$} & $0.000953^{\star *}$ & $0.00114^{\star *}$ & $0.00109^{\star *}$ & $0.00111^{* *}$ & $0.00108^{* *}$ \\
\hline & $(0.00048)$ & $(0.00045)$ & $(0.00045)$ & $(0.00046)$ & $(0.0005)$ \\
\hline \multirow[t]{2}{*}{$\log ($ income $)$} & $0.455^{\star \star \star}$ & $0.448^{* * *}$ & $0.449^{* * *}$ & $0.445^{\star \star *}$ & $0.459^{* \star *}$ \\
\hline & $(0.0495)$ & $(0.0503)$ & $(0.0496)$ & $(0.0489)$ & $(0.0612)$ \\
\hline \multicolumn{6}{|l|}{ Local spatial variables } \\
\hline \multirow[t]{2}{*}{ Land-use diversity (index) } & & $-0.190^{* *}$ & $-0.174^{\star *}$ & & $-0.182^{\star *}$ \\
\hline & & $(0.0779)$ & $(0.0769)$ & & $(0.0916)$ \\
\hline \multirow[t]{2}{*}{ Green space (fraction within $5 \mathrm{~km}$ ) } & & -0.0742 & & 0.00397 & \\
\hline & & $(0.118)$ & & $(0.117)$ & \\
\hline \multicolumn{6}{|l|}{ Relative distance to core } \\
\hline Top quartile (closest) & & -- & -- & -- & -- \\
\hline \multirow[t]{2}{*}{ 2nd quartile } & & -0.0838 & -0.0827 & -0.0905 & -0.0763 \\
\hline & & $(0.0790)$ & $(0.0796)$ & $(0.0785)$ & $(0.0665)$ \\
\hline \multirow[t]{2}{*}{ 3rd quartile } & & 0.00611 & -0.00350 & -0.0140 & -0.00246 \\
\hline & & $(0.0679)$ & $(0.0620)$ & $(0.0677)$ & $(0.0664)$ \\
\hline \multirow[t]{2}{*}{ 4th quartile (farthest) } & & -0.116 & $-0.138^{\star *}$ & -0.129 & $-0.133^{\star *}$ \\
\hline & & $(0.0765)$ & $(0.0572)$ & $(0.0802)$ & $(0.0660)$ \\
\hline Country-level effects $\left(N_{c}=5\right)$ & Fixed $^{\star \star \star}$ & Fixed $^{\star * *}$ & Fixed $^{\star * *}$ & Fixed $^{\star \star *}$ & (collinear) \\
\hline City-level effects $\left(N_{f}=33\right)$ & Random & Random & Random & Random & Fixed $^{* \star *}$ \\
\hline Observations & 1,964 & 1,964 & 1,964 & 1,964 & 1,964 \\
\hline Degrees of freedom & 15 & 20 & 19 & 19 & 47 \\
\hline Log-likelihood & $-3,821$ & $-3,817$ & $-3,817$ & $-3,819$ & $-3,790$ \\
\hline Generalized $R^{2}$ & 0.0969 & 0.101 & 0.101 & 0.0993 & 0.125 \\
\hline Log-likelihood Ratio & 1 & 9.297 & $8.978^{*}$ & 5.085 & $61.70^{* * *}$ \\
\hline
\end{tabular}

Robust standard errors in parentheses. ${ }^{* * *} p<0.01,{ }^{* *} p<0.05,{ }^{*} p<0.1$ 
Table 6: Effects of regional and local factors on life satisfaction

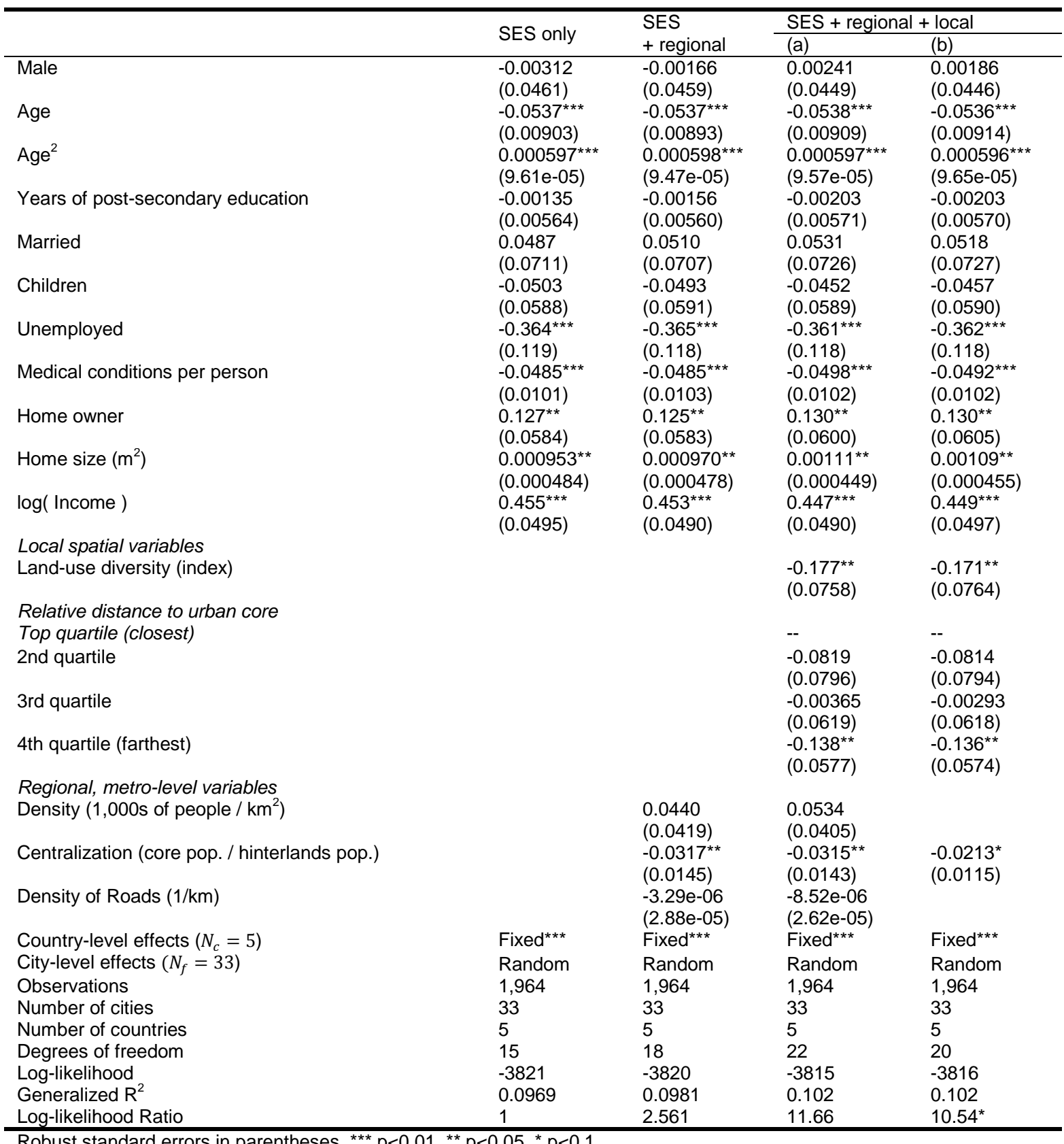




\section{CONCLUSIONS}

This paper provides evidence for a life satisfaction trade-off between home size and distance to the city centre. City compactness has a negative association with life satisfaction. No evidence is found that population density, green space or congestion have an impact on life satisfaction. Finally, empirical results reveal that land-use diversity in a household's neighbourhood has a negative effect on life satisfaction.

All of these findings deserve to be probed further. For example, what is it about compactness that negatively affects life satisfaction? Perhaps the negative externalities of congestion are exacerbated for those living in the core, without any enhancements to the positive agglomeration externalities hypothesised (and not observed here) from overall population density. Furthermore, compactness may also alienate the remaining households living in the hinterlands.

With respect to the negative relationship between local land-use diversity and life satisfaction, a number of possible explanations exist, with the aid of hindsight. One possible explanation is that each household has its own preferred land-use for the local neighbourhood (e.g. more green space, more urban amenities, etc...). If this is true, then increasing the proportion of mixed-use areas around the city reduces the potential for households to efficiently sort into those types of neighbourhoods they would prefer. An alternative explanation relates to the nature of the data: as stated above, the present data only measure the distribution among seven rather coarsely defined land-use types. This high level of aggregation may be hiding what aspects of land use really determine life satisfaction. This is especially true regarding the aggregation of urban uses, as data do not allow fine distinctions between them (e.g. commercial centres, industrial zones, cultural heritage, urban amenities), with the exception of the distinction between urban fabric and urban green.

Similarly, with the road density indicator (which varies only between cities), it would also be desirable to calculate each household's estimated distance to a high-speed road, as a measure of local noise and air pollution, for example. This could allow the city-level road density indicator to serve as a better proxy for congestion. Similarly, it would also be useful, based on previous studies' (Brereton, Clinch and Ferreira, 2008), to obtain localised measures of households' distance to airports and the sea, for example. Finally, the study would benefit from incorporating relevant price data, in particular local real estate prices, into the analysis. In standard urban economics models, the equilibrium price gradient is intrinsically linked to utility (and by hypothesis life satisfaction) in that the former equalizes the latter across space. In some sense, the observed life satisfaction differentials across space (controlling for household characteristics) represent a degree of disequilibrium that should be reflected in housing price gradients.

Even with the present data, however, there are a number of directions for further econometric analysis. One possibility is the use of GIS data as instruments to study the role of specific perceptions about local environmental quality on life satisfaction, such as satisfaction with green space access or dissatisfaction with air quality or noise levels. The appeal of this approach is that the measurement error associated with GIS data should be orthogonal to the measurement error in the survey instrument. One challenge, however, is appropriately specifying the exclusion restrictions. For example, population density may be a good instrument for dissatisfaction about local noise levels, but density also can touch on numerous other, positive aspects of life satisfaction (as discussed above).

Notwithstanding the exploratory nature of the statistical results presented here, some policy implications can be drawn. The most robust empirical result presented is that residents of cities with greater levels of centralisation - i.e. a greater share of the population living in the city centre - exhibit measurably lower levels of life satisfaction, controlling for a large range of other factors. A naïve 
interpretation of this result would suggest that anti-sprawl policies do not in fact improve overall welfare (a conclusion which this study does not support). It does, however, give cause for consideration before accepting the 'win-win' arguments for 'smart growth,' often brought forward to support increasingly concentrated, high-density development. The evidence presented here suggests that such policies are not without their welfare trade-offs, and that there will be winners and losers from their implementation. While high-density policies can clearly have a positive impact in reducing local and global environmental externalities, many of these benefits are deferred and may largely accrue to future generations.

A key general lesson from this study is that compensation of the losers may improve the equity effects of these policies (as well as prove more expeditious from a political economy perspective). One of the simplest approaches to compensation would be to balance pecuniary incentives for smart growth, such as higher development taxes or fees, with compensatory policies, such as subsidies or tax or fee offsets in other domains. For example, a local fuel tax increase to address local congestion and pollution issues could be balanced with a revenue-neutral expansion of public transport, either through an expansion of service or an expansion of subsidised user fees. This is just one example among an array of possible approaches. The main policy conclusion from this study is that smart growth policies should include distributional analysis and recommendations for addressing concerns about inequities flowing from the scoping and implementation of policies. 
ENV/WKP(2015)16

\section{REFERENCES}

Adler, M. (2012), Well-being and fair distribution: beyond cost-benefit analysis, Oxford University Press.

Bottan, N.L. and R. Perez Truglia (2011), "Deconstructing the Hedonic Treadmill: Is Happiness Autoregressive?", The Journal of Socio-Economics, Vol. 40, pp. 224-236.

Brereton, F., J.P. Clinch and S. Ferreira (2008), "Happiness, Geography and the Environment", Ecological Economics, Vol. 65, pp. 386-396.

Callegaro, M. and C. DiSogra (2008), "Computing Response Metrics for Online Panels", Public Opinion Quarterly, Vol. 72, pp. 1008-1032.

Deaton, A. (2008), "Income, Health and Wellbeing Around the World: Evidence from the Gallup World Poll", The Journal of Economic Perspectives: A Journal of the American Economic Association, Vol. 22, p. 53.

Ferreira, S. et al. (2013), "Life Satisfaction and Air Quality in Europe”, Ecological Economics, Vol. 88, pp. $1-10$.

Fleurbaey, M. (2009), "Beyond GDP: The Quest for a Measure of Social Welfare", Journal of Economic Literature, Vol. 47/4, pp. 1029-1075.

Frank, L.D. and P.O. Engelke (2001), "The Built Environment and Human Activity Patterns: Exploring the Impacts of Urban Form on Public Health", Journal of Planning Literature, Vol. 16, pp. 202-218.

Fujita, M. and J-F. Thisse (2013), Economics of Agglomeration: Cities, Industrial Location, and Globalization, Cambridge University Press.

Glaeser, E.L., S.S. Rosenthal and W.C. Strange (2010), "Urban Economics and Entrepreneurship", Journal of Urban Economics, Vol. 67, pp. 1-14.

Greene, W. H. (2003), Econometric Analysis, 5th Ed., Pearson Edication, Upper Saddle River, NJ.

Kahneman, D. and A.B. Krueger (2006), "Developments in the Measurement of Subjective Well-Being", The Journal of Economic Perspectives, Vol. 20, pp. 3-24.

Kopmann, A. (2014), "Understanding the Urban-Rural Well-being Gradient: A Spatial Analysis of Regional Amenities", Conference paper, in World Congress of Environmental and Resource Economists, Istanbul.

MacKerron, G. and S. Mourato (2009), "Life Satisfaction and Air Quality in London", Ecological Economics, Vol. 68, pp. 1441-1453.

Marshall, A. (1890), Principles of Economics, Macmillan and Co. Ltd., London.

McConnell, V. and M.A. Walls (2005), The value of open space: Evidence from studies of nonmarket benefits, Resources for the Future, Washington, D.C. 
OECD (2015), The Metropolitan Century : Understanding Urbanisation and its Consequences, OECD Publishing, Paris, http://dx.doi.org/10.1787/9789264228733-en.

OECD (2014), Greening Household Behaviour: Overview from the 2011 Survey - Revised edition, OECD Studies on Environmental Policy and Household Behaviour, OECD Publishing, Paris, http://dx.doi.org/10.1787/9789264214651-en.

OECD (2013), OECD Guidelines on Measuring Subjective Well-being, OECD Publishing, Paris, http://dx.doi.org/10.1787/9789264191655-en.

OECD (2013), "What is green growth in cities?", in OECD, Green Growth in Cities, OECD Publishing, Paris, http://dx.doi.org/10.1787/9789264195325-4-en.

OECD (2012), OECD Environmental Outlook to 2050: The Consequences of Inaction, OECD Publishing, Paris, http://dx.doi.org/10.1787/9789264122246-en.

OECD (2012), Redefining "Urban": A New Way to Measure Metropolitan Areas, OECD Publishing, Paris, http://dx.doi.org/10.1787/9789264174108-en.

Powdthavee, N. (2008), "Putting a Price Tag on Friends, Relatives, and Neighbours: Using Surveys of Life Satisfaction to Value Social Relationships", The Journal of Socio-Economics, Vol. 37, pp. 14591480 .

Rehdanz, K. and D. Maddison (2008), "Local Environmental Quality and Life-Satisfaction in Germany”, Ecological Economics, Vol. 64, pp. 787-797.

Silva, J., F.D. Keulenaer and N. Johnstone (2012), "Environmental Quality and Life Satisfaction", OECD Environment Working Papers 44.

Torrens, P. (2008), “A Toolkit for Measuring Sprawl”, Applied Spatial Analysis and Policy, Vol.1/1, pp. 536.

Van Herzele, A. and S. de Vries (2012), "Linking Green Space to Health: A Comparative Study of Two Urban Neighbourhoods in Ghent, Belgium", Population and Environment, Vol. 34, pp. 171-193.

Van Praag, B.M.S. and B.E. Baarsma (2005), "Using Happiness Surveys to Value Intangibles: The Case of Airport Noise*", The Economic Journal, Vol.115, pp. 224-246.

Welsch, H. (2002), "Preferences Over Prosperity and Pollution: Environmental Valuation Based on Happiness Surveys", Kyklos, Vol. 55, pp. 473-494.

Welsch, H. and J. Kühling (2009), "Using Happiness Data for Environmental Valuation: Issues and Applications", Journal of Economic Surveys, Vol. 23, pp. 385-406.

Wu, J. and A.J. Plantinga (2003), "The Influence of Public Open Space on Urban Spatial Structure, Journal of Environmental Economics and Management, Vol. 46, pp. 288-309. 
ENV/WKP(2015)16

\section{APPENDICES}

\section{A: Country-level results}

Table A.1: Country-level regressions

\begin{tabular}{|c|c|c|c|c|c|}
\hline $\begin{array}{l}\text { Dependent variable: LS } \\
\text { Model: ordered probit }\end{array}$ & France & Japan & Netherlands & Spain & Sweden \\
\hline \multirow[t]{2}{*}{ Male } & -0.0558 & -0.0564 & 0.0810 & -0.0365 & $0.208^{*}$ \\
\hline & $(0.0972)$ & $(0.134)$ & $(0.104)$ & $(0.0978)$ & $(0.121)$ \\
\hline \multirow[t]{2}{*}{ Age } & $-0.0418^{*}$ & $-0.0902^{* *}$ & -0.0389 & $-0.0748^{\star \star *}$ & -0.0164 \\
\hline & $(0.0247)$ & $(0.0410)$ & $(0.0287)$ & $(0.0275)$ & $(0.0319)$ \\
\hline \multirow[t]{2}{*}{$\mathrm{Age}^{2}$} & 0.000379 & $0.000940^{* *}$ & 0.000459 & $0.00086^{* * *}$ & 0.000207 \\
\hline & $(0.000288)$ & $(0.000436)$ & $(0.000323)$ & $(0.000318)$ & $(0.000354)$ \\
\hline \multirow[t]{2}{*}{ Years of post-secondary ed. } & 0.00731 & 0.00271 & $-0.0277^{*}$ & -0.00511 & 0.0311 \\
\hline & $(0.0200)$ & $(0.0153)$ & $(0.0144)$ & $(0.0157)$ & $(0.0251)$ \\
\hline \multirow[t]{2}{*}{ Married } & 0.147 & $0.339^{\star *}$ & 0.0983 & -0.0353 & -0.175 \\
\hline & $(0.114)$ & $(0.158)$ & $(0.121)$ & $(0.113)$ & $(0.153)$ \\
\hline \multirow[t]{2}{*}{ Children } & $-0.241^{* *}$ & -0.0441 & 0.0531 & 0.0297 & -0.0911 \\
\hline & $(0.113)$ & $(0.167)$ & $(0.134)$ & $(0.116)$ & $(0.165)$ \\
\hline \multirow[t]{2}{*}{ Unemployed } & $-0.821^{\star \star \star}$ & -0.0513 & $-1.110^{\star \star \star}$ & -0.00455 & $-0.416^{\star}$ \\
\hline & $(0.231)$ & $(0.300)$ & $(0.304)$ & $(0.179)$ & $(0.216)$ \\
\hline \multirow[t]{2}{*}{ Medical conditions per person } & $-0.0622^{\star \star}$ & -0.0272 & $-0.102^{\star \star \star}$ & -0.0297 & $-0.0745^{\star \star}$ \\
\hline & $(0.0283)$ & $(0.0290)$ & $(0.0321)$ & $(0.0230)$ & $(0.0315)$ \\
\hline \multirow[t]{2}{*}{ Home owner } & $0.266^{* *}$ & $0.253^{*}$ & -0.0616 & -0.0210 & 0.220 \\
\hline & $(0.111)$ & $(0.136)$ & $(0.124)$ & $(0.133)$ & $(0.148)$ \\
\hline \multirow[t]{2}{*}{ Home size $\left(m^{2}\right)$} & 0.00201 & -0.000399 & 0.00143 & 0.00169 & 0.00132 \\
\hline & $(0.00135)$ & $(0.00133)$ & $(0.000895)$ & $(0.00120)$ & $(0.00150)$ \\
\hline \multirow[t]{2}{*}{$\log$ ( income ) } & $0.487^{* * *}$ & $0.659^{* * *}$ & 0.120 & $0.423^{* * *}$ & $0.374^{\star *}$ \\
\hline & $(0.144)$ & $(0.141)$ & $(0.148)$ & $(0.109)$ & $(0.184)$ \\
\hline \multicolumn{6}{|l|}{ Relative distance to core } \\
\hline Top quartile (closest) & -- & -- & -- & -- & -- \\
\hline \multirow[t]{2}{*}{ 2nd quartile } & $-0.356^{\star * *}$ & 0.0869 & -0.0276 & 0.000292 & -0.0726 \\
\hline & $(0.126)$ & $(0.186)$ & $(0.153)$ & $(0.138)$ & $(0.170)$ \\
\hline \multirow[t]{2}{*}{ 3rd quartile } & $-0.231^{*}$ & 0.237 & -0.0262 & -0.131 & $0.406^{\star \star}$ \\
\hline & $(0.135)$ & $(0.182)$ & $(0.147)$ & $(0.144)$ & $(0.168)$ \\
\hline \multirow[t]{2}{*}{ 4th quartile (farthest) } & $-0.308^{* *}$ & -0.266 & -0.00583 & -0.0582 & 0.0810 \\
\hline & $(0.134)$ & $(0.191)$ & $(0.157)$ & $(0.145)$ & $(0.177)$ \\
\hline \multirow[t]{2}{*}{ Land-use diversity (index) } & 0.0699 & -0.242 & -0.191 & -0.0355 & -0.113 \\
\hline & $(0.155)$ & $(0.254)$ & $(0.212)$ & $(0.220)$ & $(0.203)$ \\
\hline \multirow[t]{2}{*}{ Centralization } & -0.0226 & -0.00424 & 0.0653 & $-0.194^{\star * *}$ & -0.0646 \\
\hline & $(0.0335)$ & $(0.0176)$ & $(0.0541)$ & $(0.0531)$ & $(0.0846)$ \\
\hline Observations & 502 & 290 & 428 & 447 & 297 \\
\hline Degrees of freedom & 16 & 16 & 16 & 16 & 16 \\
\hline Log likelihood & -958.8 & -594.7 & -683.3 & -865.8 & -606.6 \\
\hline Generalized $\mathrm{R}^{2}$ & 0.169 & 0.219 & 0.119 & 0.0985 & 0.154 \\
\hline
\end{tabular}

Robust standard errors in parentheses. ${ }^{* *} p<0.01,{ }^{* *} p<0.05,{ }^{*} p<0.1$ 


\section{B: Correlations of control variables and multicollinearity}

Potential issues with multicollinearity in the control variables of the regression analysis were investigated through the computation of the 'variance inflation factor' (VIF). In summary, the VIF computes how much the standard error estimates of a coefficient associated with a given regressor are inflated due to correlation of this regressor with other explanatory variables in the regression (Greene, 2003). A higher VIF means greater multicollinearity. Different values of the VIF - typically 20,10 and 5 have been proposed as a threshold above which concerns about multicollinearity are warranted and the precision of regression estimates are suspect. The standard VIF is defined for a linear regression (i.e. not the random effects ordered probit model used in Table 5 of the paper). To investigate potential issues of multicollinearity in the control variables, we therefore estimate a simple linear regression of life satisfaction on the control variables and country fixed effects and then estimate the VIF for each control variable, as well as the mean VIF across all of the controls. As shown below, the maximum VIF is 1.82, well below any of the thresholds warranting concern. We find no evidence that multicollinearity of the control variables is a concern in the regression analysis.

Table B.1: Variance inflation factors (VIF) for survey covariates in the regression analysis

\begin{tabular}{ll}
\hline Explanatory variable & VIF \\
\hline Male & 1.05 \\
Age & 1.31 \\
Years of post-secondary education & 1.14 \\
Married & 1.42 \\
Children & 1.24 \\
Unemployed & 1.07 \\
Medical conditions per person & 1.14 \\
Home owner & 1.23 \\
Home size & 1.27 \\
log( Income ) & 1.55 \\
& \\
Country fixed-effects & \\
France & -- \\
Japan & 1.5 \\
Netherlands & 1.73 \\
Spain & 1.82 \\
Sweden & 1.48 \\
& \\
Mean & 1.35 \\
\hline
\end{tabular}

\section{C: Sensitivity analysis of localised geospatial variables}

The choice of the radius of the "local environment" around the household is arbitrary, and constrained by different data issues. Theoretically, a rather small radius of 1 or $2 \mathrm{kms}$ (walkable distance) around the household would be proper "local vicinity". As the exact location of households within their postal code is not known, the coordinates used to locate each household are those of the centre of the postal code the 
household belongs to. The ideal would have been to use postal code areas as the "local vicinity" of households, but unfortunately postal code shapes were not available freely for all those countries at the time of this study. In the absence of such data, we define a radius around the centre of the postal code and define this area as the "local vicinity" of the household. Hence, the choice of the size of this radius is driven by two opposite constraints: A large radius increases the chance of including the actual position of the household, but reduces the variability of the composition of local land use between households, and consequently the potential explanatory power of the index of land composition. A small radius increases the variability between households' vicinities, but increases the risk of missing the actual household location. In addition, the mean sizes of the postal code areas are variable among countries and regions, but as we concentrate on Functional Urban Areas, we focus on dense areas in which sizes of postal codes are likely to be reduced.

We tested different radii of "local environment". Table C.1 presents the results for the specification (a) of the model (SES variables + local variables). As we see the Radius has no incidence on the effect of the proportion of green space around households (always insignificant), but does have an effect on the significance of the Shannon Weaver index of diversity. For every Radius length from 2 to $10 \mathrm{~km}$, the effect of the Local Diversity index on well-being is negative. As expected above, when the diversity index is calculated using large radius ( $>5 \mathrm{~km})$, it loses its explanatory power on household well-being, and its effect is insignificant. This could suggest that above a certain radius, the "local vicinity" is too large and becomes irrelevant, while a smaller radius captures the characteristics of household local environment, even if it is not the exact position of the household, hypothesising that the postal code area composition in land uses is quite homogeneous. 


\section{ENV/WKP(2015)16}

Table C.1: Sensitivity of regression results to the boundary radius for local environmental variables

\begin{tabular}{|c|c|c|c|c|c|c|c|c|c|}
\hline $\begin{array}{l}\text { Radius } \mathrm{R} \text { of "local } \\
\text { environment" around } \\
\text { household }\end{array}$ & $2 \mathrm{~km}$ & $3 \mathrm{~km}$ & $4 \mathrm{~km}$ & $5 \mathrm{~km}$ & $6 \mathrm{~km}$ & $7 \mathrm{~km}$ & $8 \mathrm{~km}$ & $9 \mathrm{~km}$ & $10 \mathrm{~km}$ \\
\hline $\begin{array}{l}\text { Set of Socioeconomic } \\
\text { individual variables }\end{array}$ & yes & yes & yes & yes & yes & yes & yes & yes & yes \\
\hline \multicolumn{10}{|l|}{ Distance to Core : } \\
\hline \multirow[t]{2}{*}{ Q2 vs Q1 } & -0.0729 & -0.0750 & -0.0803 & -0.0842 & -0.0854 & -0.0860 & -0.0866 & -0.0873 & -0.0893 \\
\hline & $(0.0816)$ & $(0.0835)$ & $(0.0813)$ & $(0.0788)$ & $(0.0793)$ & $(0.0790)$ & $(0.0787)$ & $(0.0785)$ & $(0.0758)$ \\
\hline \multirow[t]{2}{*}{ Q3 vs Q1 } & 0.0245 & 0.00125 & -0.00710 & 0.00774 & -0.0154 & -0.0176 & -0.0180 & -0.0171 & -0.00363 \\
\hline & $(0.0742)$ & $(0.0742)$ & $(0.0722)$ & $(0.0674)$ & $(0.0674)$ & $(0.0659)$ & $(0.0653)$ & $(0.0650)$ & $(0.0632)$ \\
\hline \multirow[t]{2}{*}{ Q4 vs Q1 } & -0.0848 & -0.137 & $-0.147^{\star}$ & -0.115 & $-0.153^{\star *}$ & $-0.156^{\star *}$ & $-0.155^{\star *}$ & $-0.152^{\star *}$ & $-0.123^{*}$ \\
\hline & $(0.0899)$ & $(0.0898)$ & $(0.0847)$ & $(0.0759)$ & $(0.0771)$ & $(0.0738)$ & $(0.0722)$ & $(0.0708)$ & $(0.0643)$ \\
\hline \multirow[t]{2}{*}{ Land-use diversity (index) } & $-0.220^{* *}$ & $\begin{array}{l}-7.02 \mathrm{e}- \\
05^{\star}\end{array}$ & $\begin{array}{l}-3.29 e- \\
05^{\star}\end{array}$ & $-0.210^{* * *}$ & $-9.64 e-06$ & $-6.41 e-06$ & $-4.08 e-06$ & $-2.90 e-06$ & -0.175 \\
\hline & $(0.0878)$ & $\begin{array}{l}(4.07 e- \\
05)\end{array}$ & $\begin{array}{l}(1.99 \mathrm{e}- \\
05)\end{array}$ & $(0.0785)$ & $\begin{array}{l}(7.84 \mathrm{e}- \\
06)\end{array}$ & $\begin{array}{l}6.02 \mathrm{e}- \\
06)\end{array}$ & $\begin{array}{l}(5.03 \mathrm{e}- \\
06)\end{array}$ & $\begin{array}{l}(4.64 \mathrm{e}- \\
06)\end{array}$ & -0.102 \\
\hline Green space & -0.0336 & $8.79 e-06$ & $4.67 e-06$ & -0.0823 & $3.44 \mathrm{e}-06$ & $3.81 \mathrm{e}-06$ & $3.41 \mathrm{e}-06$ & $2.46 e-06$ & -0.122 \\
\hline Observations & 1,964 & 1,964 & 1,964 & 1,964 & 1,964 & 1,964 & 1,964 & 1,964 & 1,964 \\
\hline Number of groups & 33 & 33 & 33 & 33 & 33 & 33 & 33 & 33 & 33 \\
\hline Degrees of freedom & 20 & 20 & 20 & 20 & 20 & 20 & 20 & 20 & 20 \\
\hline Log likelihood & -3814 & -3816 & -3817 & -3816 & -3818 & -3818 & -3818 & -3818 & -3817 \\
\hline Gen. $R^{\wedge} 2$ & 0.103 & 0.102 & 0.101 & 0.102 & 0.0999 & 0.0999 & 0.0997 & 0.0996 & 0.100 \\
\hline $\log L R$ & 13.71 & 10.32 & 8.415 & 10.53 & 6.527 & 6.410 & 6.133 & 5.895 & 7.657 \\
\hline logLR (p-value) & 0.0167 & 0.0942 & 0.208 & 0.0858 & 0.393 & 0.407 & 0.440 & 0.469 & 0.274 \\
\hline
\end{tabular}

